\title{
Manganese and rhenium triphosphorus macrocycle complexes and reactions with alkenes
}

\author{
Robert J. Baker, ${ }^{a}$ Peter G. Edwards, ${ }^{* a}$ Jesús Gracia-Mora, ${ }^{b}$ Florent Ingold ${ }^{a}$ and \\ K. M. Abdul Malik ${ }^{a}$ \\ ${ }^{a}$ Department of Chemistry, Cardiff University, P. O. Box 912, Cardiff, UK CF10 3TB \\ ${ }^{b}$ Departamento de Química Inorgánica, Facultad de Química, UNAM, Ciudad Universitaria, \\ México D. F., 04510, Mexico
}

Received 13th June 2002, Accepted 20th August 2002

First published as an Advance Article on the web 8th October 2002

\begin{abstract}
The synthesis of $\operatorname{Re}(\mathrm{III}), \operatorname{Re}(\mathrm{I})$ and $\mathrm{Mn}(\mathrm{I})$ compounds of the macrocyclic phosphine ligand 1,5,9-trialkyl-1,5,9triphosphacyclododecane, $12[$ ane $] \mathrm{P}_{3} \mathrm{R}_{3}\left(\mathrm{R}=\mathrm{Et},{ }^{\mathrm{i}} \mathrm{Bu}\right)$ is described. The reaction of $12[\operatorname{ane}] \mathrm{P}_{3} \mathrm{R}_{3}$ with $\mathrm{ReCl}_{3}\left(\mathrm{PPh}_{3}\right)_{2}{ }^{-}$ $\left(\mathrm{CH}_{3} \mathrm{CN}\right)$ or $\mathrm{ReCl}_{3}\left(\mathrm{PPhMe}_{2}\right)_{3}$ gives rise to the octahedral d ${ }^{4}$ complexes $\left(12[\operatorname{ane}] \mathrm{P}_{3} \mathrm{R}_{3}\right) \mathrm{ReCl}_{3}\left(\mathbf{1}^{\mathrm{R}}\right)$. Reduction of $\mathbf{1}^{\mathbf{i B u}}$ with $\mathrm{Na} / \mathrm{Hg}$ under a $\mathrm{CO}$ atmosphere gives the rhenium(I) compound $\left(12[\right.$ ane $\left.] \mathrm{P}_{3} \mathrm{R}_{3}\right) \operatorname{Re}(\mathrm{CO}){ }_{2} \mathrm{Cl}, \mathbf{2}^{\mathrm{R}}$ which undergoes further reactivity to give hydride $\left(3^{\mathbf{R}}\right)$, vinylidene $\left(4^{\mathbf{R}}\right)$ and allenylidene $\left(5^{\mathrm{R}}\right)$ compounds. With $\mathrm{Mn}(\mathrm{CO})_{5} \mathrm{Br}, 12[\mathrm{ane}] \mathrm{P}_{3} \mathrm{Et}_{3}$ gives the octahedral $\mathrm{d}^{6}$ complex, $\left(12[\mathrm{ane}] \mathrm{P}_{3} \mathrm{Et}_{3}\right) \mathrm{Mn}(\mathrm{CO})_{2} \mathrm{Br}, 6^{\mathrm{Et}}$. The crystal structures of $\left(12[\mathrm{ane}] \mathrm{P}_{3}{ }^{\mathrm{i}} \mathrm{Bu}_{3}\right) \mathrm{ReCl}_{3}$ and $\left(12[\mathrm{ane}] \mathrm{P}_{3} \mathrm{Et}_{3}\right) \mathrm{Mn}(\mathrm{CO}){ }_{2} \mathrm{Br}$ are presented.
\end{abstract}

\section{Introduction}

We are interested in the application of multidentate and macrocyclic phosphines due to their ability to form robust metalligand units and also potentially control coordination geometry and shape in their metal complexes. The macrocyclic coordination effect does indeed impart substantial robustness in these macrocycle complexes in comparison to analogous acyclic ligand systems and this robustness appears to be a factor leading to catalytic activity for which metal phosphine complexes are typically not well noted. This is exemplified in our recent study ${ }^{1}$ of the coordination behaviour of the 12-membered triphosphorus macrocycle, 12 [ane] $\mathrm{P}_{3} \mathrm{R}_{3}$, and its complexes of the early first row transition metal halides of $\mathrm{Ti}, \mathrm{V}, \mathrm{Cr}$ which all show alkene polymerisation activity. ${ }^{1 b}$ The coordination properties of these ligands with heavier transition elements has not been investigated in detail, the only reported third row transition metal complex being $\left(12[\right.$ ane $\left.] \mathrm{P}_{3} \mathrm{H}_{3}\right) \mathrm{W}(\mathrm{CO})_{3}{ }^{2}$. The influences these ligands may have upon the reactivity of their complexes may be of significant value, especially in view of their ability to act as facially capping six-electron donors which require remaining ligands to occupy mutually $c i s$ positions. In view of the catalytic activity of rhenium compounds in alkene metathesis, ${ }^{3}$ the properties of rhenium complexes of phosphorus macrocycles are of interest. In comparison, the chemistry of manganese-phosphine complexes differs significantly from that of its heaviest congener in a number of respects and we have previously shown that triphosphacyclododecanes are capable of stabilising metal complexes with a range of metals of differing radii. ${ }^{4}$ Consequently, we have chosen to study the coordination properties of these ligands with both manganese and rhenium and in this paper, we report the synthesis of a range of $\operatorname{Re}(\mathrm{III}), \operatorname{Re}(\mathrm{I})$ and $\mathrm{Mn}(\mathrm{I})$ compounds. We also report on a study of the reactivity of the $\operatorname{Re}(\mathrm{I})$ and $\mathrm{Mn}(\mathrm{I})$ compounds towards alkenes and applications in ring opening metathesis polymerisation catalysis. As ruthenium phosphine complexes are also now well established in ROMP catalysis, we compare the reactivity of the new $\mathrm{Re}$ and $\mathrm{Mn}$ compounds with that of a related ruthenium macrocycle derivative.

\section{Results and discussion}

\section{Rhenium(III) complexes}

Addition of $12[a \mathrm{ane}] \mathrm{P}_{3} \mathrm{Et}_{3}$ or the bulkier $12[\mathrm{ane}] \mathrm{P}_{3}{ }^{\mathrm{i}} \mathrm{Pr}_{3}$ to $\mathrm{ReCl}_{3}\left(\mathrm{PPh}_{3}\right)_{2}(\mathrm{MeCN})$ gives rise to green powders which are insoluble in all common solvents, except hot DMSO in which they decompose. These compounds were not further investigated since reaction with $12[\mathrm{ane}] \mathrm{P}_{3} \mathrm{Bu}_{3}^{\mathrm{i}}$ gives rise to a dichloromethane soluble green solid $\left(1^{\mathrm{i} \mathbf{B u}}\right)$. The same compound can be obtained from mer- $\mathrm{ReCl}_{3}\left(\mathrm{PMe}_{2} \mathrm{Ph}\right)_{3}$, albeit in lower yields and in both cases the reaction can be followed by monitoring the decay of free macrocycle and growth of $\mathrm{PPh}_{3}$ or $\mathrm{PMe}_{2} \mathrm{Ph}$ respectively in the ${ }^{31} \mathrm{P}$ NMR spectrum. $1^{\mathrm{iBu}}$ is obtained as an air stable green powder, after workup, which is air-sensitive in solution and readily oxidises yielding unidentified brown paramagnetic solutions that do not contain a $\mathrm{Re}=\mathrm{O}$ unit (by IR). $\mathbf{1}^{i \mathbf{B u}}$ has been characterised by spectroscopic and analytical methods. The formula $\left(12[\mathrm{ane}] \mathrm{P}_{3}{ }^{\mathrm{i}} \mathrm{Bu}_{3}\right) \mathrm{ReCl}_{3}$ is confirmed by mass spectrometry in which the molecular ion is observed which displays the expected characteristic isotope pattern for $\mathrm{Re}$ and $\mathrm{Cl}$. The complex is paramagnetic with a magnetic susceptibility $\left(\mu_{\text {eff }}=1.42 \mu_{\mathrm{B}}\right)$ indicating a large spin-orbit coupling and is consistent with $\mathrm{d}^{4} \mathrm{Re}(\mathrm{III}){ }^{5}$ Sharp, shifted proton NMR spectra are observed which are spread over a +18 to $-5 \mathrm{ppm}$ range; the terminal ${ }^{\mathrm{i}} \mathrm{Bu}$ methyl groups, being furthest from the metal are shifted the least $(\delta=2.8$, methyl protons; $\delta=8.8$, methine protons), and these can be assigned from the ${ }^{1} \mathrm{H}-{ }^{1} \mathrm{H}$ 2D spectra which also clearly indicates the diastereotopic nature of the ligand backbone ring protons. Only the ${ }^{\mathrm{i}} \mathrm{Bu}$ methyl groups were observed in the ${ }^{13} \mathrm{C}$ NMR spectrum $(\delta=42)$ and no ${ }^{31} \mathrm{P}$ NMR signals were observed as might be expected. ${ }^{6}$ Two bands attributable to $v(\mathrm{Re}-\mathrm{Cl})$ consistent with approximate $C_{3 \mathrm{v}}$ symmetry were observed in the IR spectrum (347, $308 \mathrm{~cm}^{-1}$ ).

Cyclic voltammetry (CV) has also been used to characterise rhenium compounds and the $\mathrm{CV}$ of $\mathbf{1}^{\text {iBu }}$ clearly shows two, oneelectron reduction waves and one oxidation wave $\left(E_{1 / 2(\text { ox })}=\right.$ $\left.+0.46, E_{1 / 2 \text { (red) }}=-1.15,-1.60\right)$. The standard oxidation potential is quite different to reported data for similar com- 
plexes $\left\{\right.$ e.g. for $\left[\mathrm{PhP}\left(\mathrm{CH}_{2} \mathrm{CH}_{2} \mathrm{PPh}_{2}\right)_{2}\right] \mathrm{ReCl}_{3}, E_{1 / \text { (ox })}=+0.63$; for [triphos] $\mathrm{ReCl}_{3}, E_{1 / 2(\text { ox })}=+0.63 ; \mathrm{PP}_{2}=\mathrm{PhP}\left(\mathrm{CH}_{2} \mathrm{CH}_{2} \mathrm{PPh}_{2}\right)_{2}$, triphos $\left.=\mathrm{MeC}\left(\mathrm{CH}_{2} \mathrm{PPh}_{2}\right)_{3}\right\} .{ }^{7}$ This shows that the macrocycle complex is easier to oxidise than the other acyclic phosphine ligand complexes, i.e. the macrocycle stabilises higher oxidation states and implies that the macrocycle is a better electron donor than either the tripodal or acyclic triphosphine ligands $\left(\mathrm{PP}_{2}\right)$.

Mononuclear rhenium(III) complexes containing three tertiary phosphines and three halides are well known but the majority have meridional geometries, even those with polydentate phosphines that are flexible enough to adopt a facial configuration. ${ }^{8}$ Phosphorus ligand complexes that show a facial arrangement include $\mathrm{MeC}\left(\mathrm{CH}_{2} \mathrm{PPh}_{2}\right)_{3} \mathrm{ReCl}_{3},{ }^{7 a}$ which has been structurally characterised, and the phosphite complex, $\mathrm{ReCl}_{3}$ $\left(\mathrm{P}(\mathrm{OEt})_{3}\right)_{3}$, which is assigned a fac configuration on the basis of IR and ${ }^{1} \mathrm{H}$ spectroscopy. ${ }^{9} \mathrm{ReCl}_{3}\left(\mathrm{PR}_{3}\right)_{3}$ complexes $(\mathrm{R}=$ alkyl or aryl) may also be formed as a mixture of mer and fac isomers. ${ }^{10}$ In the present compounds, the constraints imposed by the macrocycle means that the complex must have a fac geometry and this is confirmed by a crystal structure determination.

The crystal structure of $\mathbf{1}^{\mathbf{i} \mathbf{B u}}$ is shown in Fig. 1(a) along with selected bond lengths and angles. The $\mathrm{Re}, \mathrm{Cl}(1), \mathrm{P}(2)$ and central carbon of the backbone propanediyl bridge opposite to $\mathrm{P}(2)$ all sit on a crystallographic mirror plane. The remaining backbone functions are disordered with the carbons bonded to $\mathrm{P}(2)$ being satisfactorily refined in two split-occupancy positions; the $\beta$-carbon of the ${ }^{i} \mathrm{Bu}$ group is similarly disordered over two positions. This model is more clearly represented in Fig. 1(b). The overall coordination geometry of $1^{i \mathrm{Bu}}$ is very close to regular octahedral, the average $\mathrm{Re}-\mathrm{P}$ bond length is similar [2.386(3) $\AA]$ to the average Re-Cl length $[2.419(2) \AA]$ and the average interligand angles are also close to $90^{\circ}[\mathrm{P}-\mathrm{Re}-\mathrm{P}=$ $\left.90.95(8)^{\circ}, \mathrm{Cl}-\mathrm{Re}-\mathrm{Cl}=92.84(8)^{\circ}\right]$. The structure gives a clear indication of the bulk of the ${ }^{\mathrm{i}} \mathrm{Bu}$ substituents and how they protrude below the girth of the complex, this feature has implications for the reactivity of complexes of this ligand (vide supra). The Re-P distances are significantly shorter than those found in (triphos) $\mathrm{ReCl}_{3}{ }^{7 a}\left[\mathrm{Re}-\mathrm{P}_{\mathrm{av}}=2.447(5) \AA\right]$, presumably due to the inflexible nature of the tripodal phosphine; the more sterically demanding phenyl groups may also help to force the ligand away from the metal centre. The $\mathrm{P}-\mathrm{Re}-\mathrm{P}$ angles in $\mathbf{1}^{\mathrm{iBu}}$ are also significantly greater than in the triphos case $(84.8,85.4$ and $86.1^{\circ}$ ) which indicates the lack of flexibility of the triphos ligand in comparison to the macrocycle.

\section{Rhenium(I) complexes}

The $\mathrm{CV}$ of $\mathbf{1}^{\mathrm{iBu}}$ shows that the $2 \mathrm{e}^{-}$reduction to a $\mathrm{d}^{6}, \mathrm{Re}(\mathrm{I})$ state should be readily accessible. Chemical reduction of $\mathbf{1}^{\mathbf{i} \mathrm{Bu}}$ using two equivalents of sodium amalgam under a $\mathrm{CO}$ atmosphere proceeded smoothly to give $12[\operatorname{ane}] \mathrm{P}_{3} \mathrm{Bu}_{3}^{i} \operatorname{Re}(\mathrm{CO})_{2} \mathrm{Cl}, 2^{\mathrm{i} \text { u }}$, in good yield. The same reaction using $\mathbf{1}^{\mathrm{Et}}$ gives the analogue, $\mathbf{2}^{\mathrm{Et}}$, in comparable yields. The spectroscopic data is consistent with the proposed structure (Scheme 1), and comparison with the NMR data for the manganese complex (described below) also suggests the same structure.

The ${ }^{31} \mathrm{P}$ NMR spectrum of $2^{\text {iBu }}$ shows the expected $\mathrm{AM}_{2}$ pattern $\left(\delta-8.72\right.$, (t) and $\left.-26.43(\mathrm{~d}) ; J_{\mathrm{AM}}=19.5 \mathrm{~Hz}\right)$ which is temperature invariant, and the infrared spectrum shows two bands of equal intensity $\left[v(\mathrm{CO})=1930\right.$ and $\left.1865 \mathrm{~cm}^{-1}\right]$ indicating a cis configuration of carbonyl ligands. Comparison of $v(\mathrm{CO})$ with the reported (triphos) $\mathrm{Re}(\mathrm{CO})_{2} \mathrm{Cl}[v(\mathrm{CO})=1948$ and $\left.1887 \mathrm{~cm}^{-1}\right]^{11}$ shows that the macrocycle is a better electron donor than triphos, and this corroborates the $\mathrm{CV}$ evidence from $\mathbf{1}^{i \mathbf{B u}}$. The ${ }^{1} \mathrm{H}$ NMR spectrum is uninformative since all the macrocycle protons resonate in the same area, except for the methyl groups of the ${ }^{i} \mathrm{Bu}$ chain $(\delta 0.95)$. The ${ }^{13} \mathrm{C}$ NMR spectrum is much more informative, especially the carbonyl resonance which is shown in Fig. 2. This shows coupling with two equatorial phosphines that are chemically equivalent but
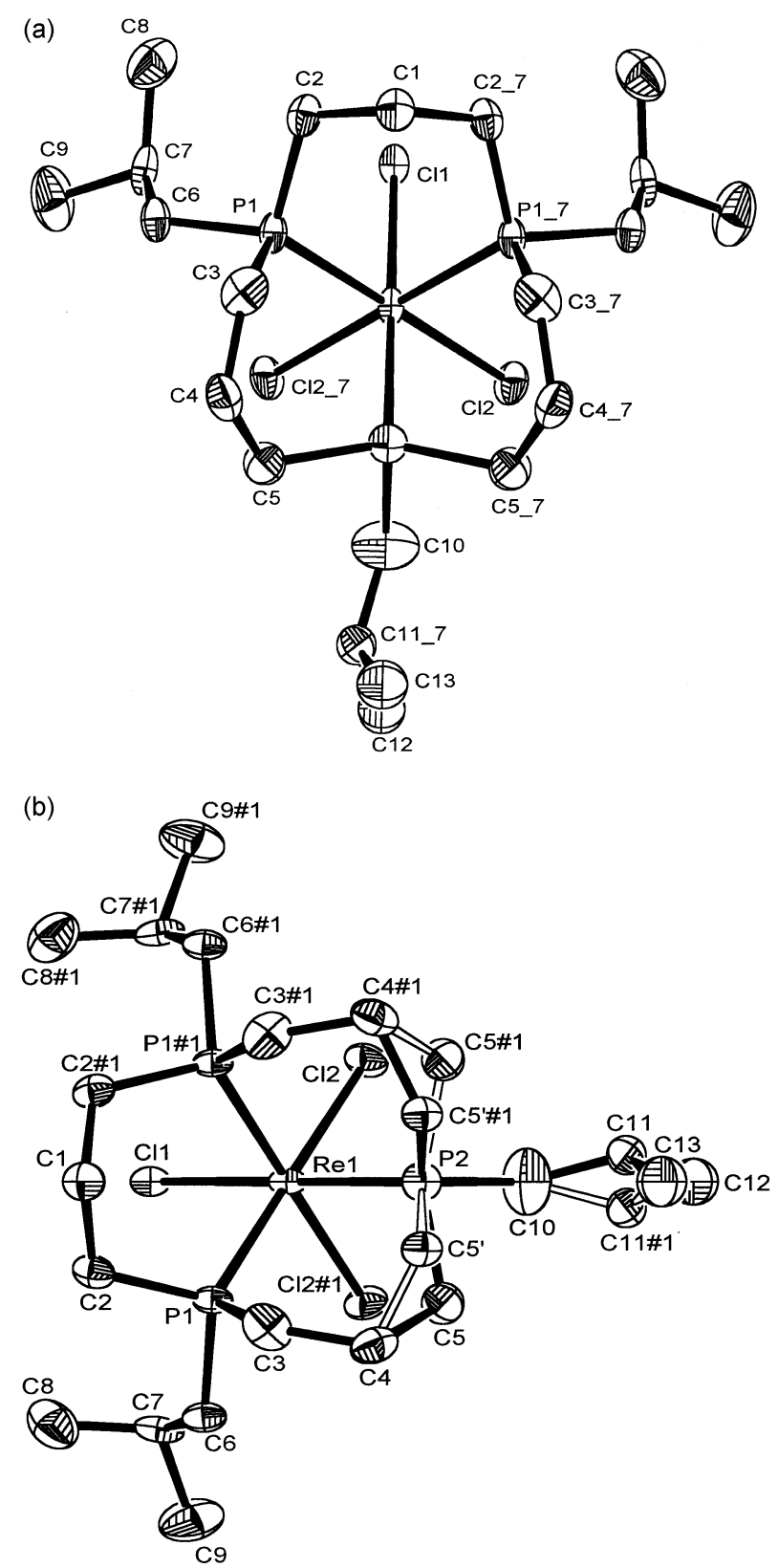

Fig. 1 (a) X-Ray structure of $\left(12[a n e] \mathrm{P}_{3}{ }^{i} \mathrm{Bu}_{3}\right) \mathrm{ReCl}_{3}, \mathbf{1}^{\mathrm{iBu}}$, showing the atom labelling scheme. (b) The C4-C5-P2 bridge and the $\mathrm{C} 11$ atoms are disordered. Thermal ellipsoids are drawn at $50 \%$ probability level. The symmetry $(x, 1 / 2-y, z)$ generates the atoms marked with $\# 1$. Selected bond lengths $(\AA)$ and angles $\left(^{\circ}\right)$ : Re-P1 2.389(2), Re-P2 2.381(3), Re-Cl1 2.411(2), Re-Cl2 2.423(2); P1-Re-P2 91.26(6), P1-Re-P1\#1 90.33(8), P1-Re-Cl1 87.84(6), P1-Re-Cl2 178.47(6), P1-Re-Cl2\#1 89.12(6), P2-Re-Cl1 178.73(9), P2-Re-Cl2 87.33(6), Cl1-Re-Cl2 93.56(6), Cl2-Re-Cl\#1 91.40(8).

magnetically inequivalent, and the one axial phosphine, to give an $\mathrm{AXX}^{\prime} \mathrm{Y}$ spin system. This compares well with data for $\left[(\text { triphos }) \mathrm{Re}(\mathrm{CO})_{2} \mathrm{Cl}\right]^{11}$ and (triphos) $\left.\mathrm{Ru}(\mathrm{CO})_{2} \mathrm{Cl}\right]^{+} .^{12}$

Direct substitution of the carbonyl groups in $\operatorname{Re}(\mathrm{CO})_{5} \mathrm{Br}$ by the macrocycle, either thermally or photolytically, occurs in poor yield and is accompanied by decomposition products which could not be separated. The kinetic inertness of $d^{6} \operatorname{Re}(\mathrm{I})$ and poor solubility may contribute to the low yield observed in this reaction as is consistent with previous observations where direct substitution of carbonyls in $\operatorname{Re}(\mathrm{CO})_{5} \mathrm{X}(\mathrm{X}=$ halide) compounds by acyclic $\mathrm{PP}_{2}$ ligands has been studied and reported to be stubborn and to give rise to mixtures of products. ${ }^{13}$ The reaction of phosphines with $\operatorname{Re}(\mathrm{CO})_{3}\left(\mathrm{PPh}_{3}\right)_{2} \mathrm{Cl}$ is known to result in substitution, ${ }^{11}$ but with the macrocycle $\left(12[\mathrm{ane}] \mathrm{P}_{3}{ }^{\mathrm{i}} \mathrm{Bu}_{3}\right.$ ) no reaction was observed over prolonged reaction times in refluxing xylene. 


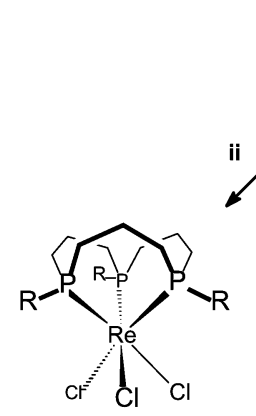

1

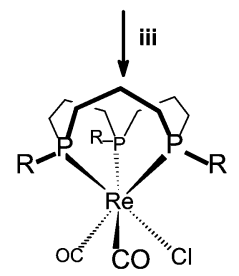

2<smiles>[R]P1CC[C@H](CC)P1[R]([R])([H])C(=O)[O-]</smiles>

3

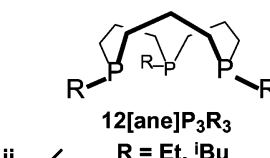

$\searrow$

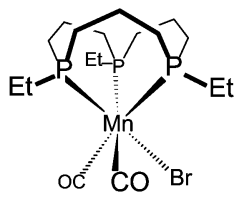

6
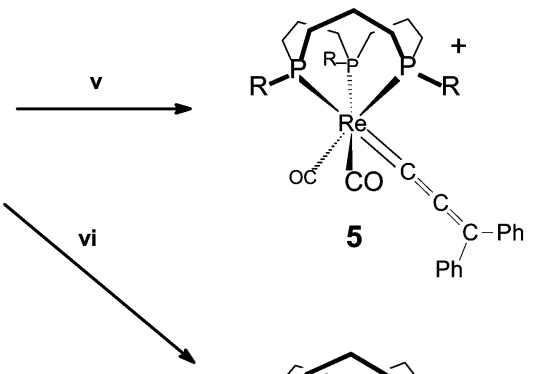

vii

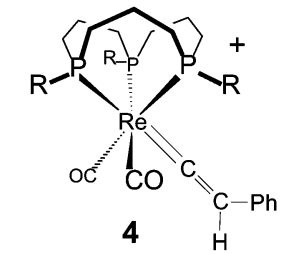

Scheme 1 Reagents and conditions: (i) $\mathrm{Mn}(\mathrm{CO})_{5} \mathrm{Br}, \mathrm{CH}_{2} \mathrm{Cl}_{2}$; (ii) $\mathrm{ReCl}_{3}\left(\mathrm{CH}_{3} \mathrm{CN}\right)\left(\mathrm{PPh}_{3}\right)_{2}, \mathrm{CH}_{2} \mathrm{Cl}_{2}$; (iii) $\mathrm{Na} / \mathrm{Hg} / \mathrm{CO}$, THF; (iv) $\mathrm{LiAlH}_{4}$ THF; (v) $\mathrm{CF}_{3} \mathrm{SO}_{3} \mathrm{Ag}, \mathrm{HC} \equiv \mathrm{CCH}_{2} \mathrm{C}(\mathrm{OH}) \mathrm{Ph}_{2}, \mathrm{CH}_{2} \mathrm{Cl}_{2}$; (vi) $\mathrm{CF}_{3} \mathrm{SO}_{3} \mathrm{Ag}$, $\mathrm{HC} \equiv \mathrm{CPh}, \mathrm{CH}_{2} \mathrm{Cl}_{2} ;$ (vii) $\mathrm{Me}_{3} \mathrm{OBF}_{4}, \mathrm{HC} \equiv \mathrm{CPh}, \mathrm{CH}_{2} \mathrm{Cl}_{2}$.

Reaction of $2^{i \mathrm{Bu}}$ with $\mathrm{LiAlH}_{4}$ proceeds under an inert atmosphere to give 12 [ane $] \mathrm{P}_{3}{ }^{i} \mathrm{Bu}_{3} \operatorname{Re}(\mathrm{CO})_{2} \mathrm{H}, 3^{i \mathrm{Bu}}$, selectively and in good yield. The analogous reaction with the related (triphos)$\mathrm{ReCl}_{3}$, under the same conditions, gives rise to a trihydride, ${ }^{14}$ an atmosphere of $\mathrm{CO}$ is required for the formation of the dicarbonyl mono-hydride. The IR spectrum of $3^{i \mathrm{Bu}}$ shows two bands due to carbonyl ligands at 1910 and $1845 \mathrm{~cm}^{-1}$ consistent with a cis orientation of the carbonyl groups and at a lower energy compared to $2^{i \mathbf{B u}}$ as a result of substitution of chloride by the more electron donating hydride. No bands attributable to $v(\mathrm{M}-\mathrm{H})$ were observed, they are presumably masked by the carbonyl absorptions. The ${ }^{31} \mathrm{P}\left\{{ }^{1} \mathrm{H}\right\}$ NMR spectrum at room appears as a broad singlet $(\delta-23.7)$ which separates into two peaks at $-20{ }^{\circ} \mathrm{C}$ in a ratio of $1: 2$; further cooling to $-90{ }^{\circ} \mathrm{C}$ gives rise to two broad singlets $(\delta-19.9,-23.4)$. This spectrum is consistent with magnetically inequivalent phosphines in a ratio of 1:2, any $\mathrm{P}-\mathrm{P}$ coupling being obscured by the line width of the peaks; the broadened ${ }^{31} \mathrm{P}$ NMR spectrum also obscures any fine structure attributable to ${ }^{2} J_{\mathrm{PH}}$. The ${ }^{1} \mathrm{H}$ NMR spectrum at room temperature shows, in addition to resonances due to macrocycle protons, a triplet attributable to the hydride resonance $\left(\delta-6.76, J_{\mathrm{P}-\mathrm{H}}=27.5 \mathrm{~Hz}\right)$ which is temperature invariant (to $-90{ }^{\circ} \mathrm{C}$ ) indicating the absence of phosphine dissociation on the NMR timescale. The analogous (triphos) $\mathrm{Re}(\mathrm{CO})_{2} \mathrm{H}$ also shows a temperature invariant triplet in the ${ }^{1} \mathrm{H}$ NMR spectrum, this is explained by a reduced interaction with the trans phosphine as a result of structural distortions. ${ }^{14}$ The ${ }^{13} \mathrm{C}$ NMR spectrum of $3^{i \mathrm{Bu}}$ is also consistent with the structure proposed, a resonance due to the carbonyl carbons appears as a poorly resolved multiplet $(\delta$ 198.4), the inequivalence of the backbone functions and the P-alkyl substituents is clearly indicated and resonances due to all carbons could be assigned; again this behaviour indicates that the complex is stereochemically rigid.

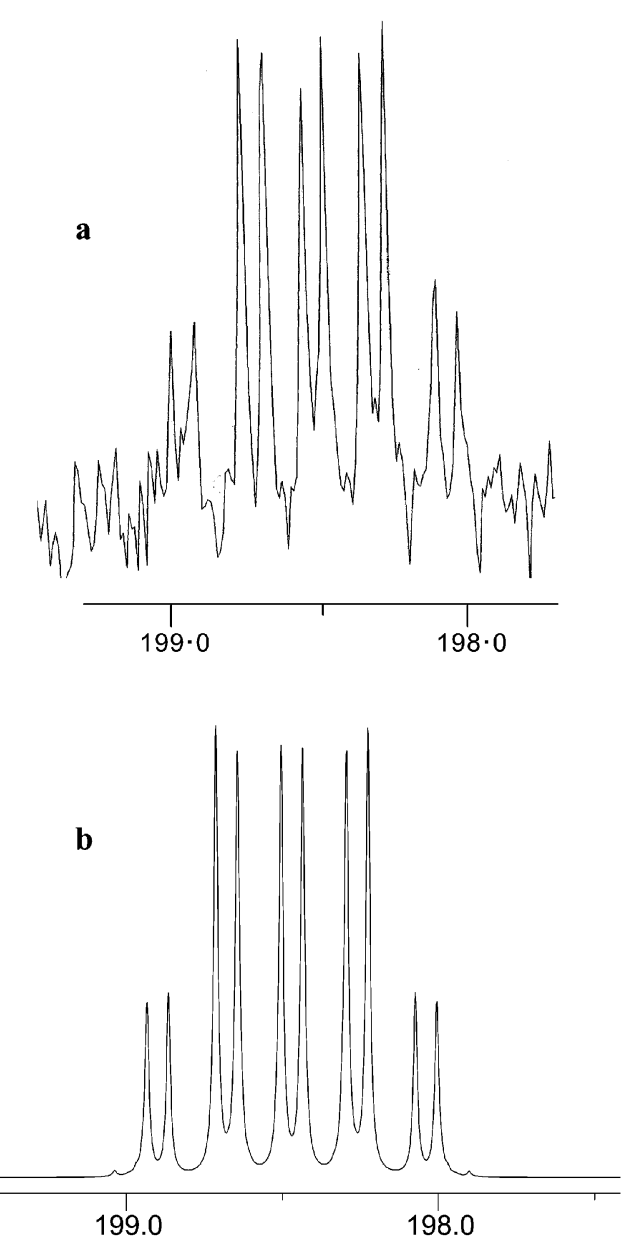

Fig. $2100 \mathrm{MHz}{ }^{13} \mathrm{C}$ NMR spectrum of $2^{i \mathrm{Bu}}$ in the carbonyl region, scale units are $\delta$. $\mathbf{a}$ : observed spectrum. $\mathbf{b}$ : calculated spectrum based on an $\mathrm{AXX}^{\prime} \mathrm{Y}$ spin system $\left(\mathrm{A}={ }^{13} \mathrm{C} ; \mathrm{X}, \mathrm{X}^{\prime}, \mathrm{Y}={ }^{31} \mathrm{P}\right), J_{\mathrm{AX}}($ cis $)=50.0 \mathrm{~Hz}$, $J_{\mathrm{AX}^{\prime}}($ trans $)=-8.0 \mathrm{~Hz}, J_{\mathrm{AY}}=7.0 \mathrm{~Hz}, J_{\mathrm{XX}^{\prime}}=32.0 \mathrm{~Hz}, J_{\mathrm{XY}}=J_{\mathrm{X}^{\prime} \mathrm{Y}}=0.5 \mathrm{~Hz}$.

In addition, the formulation is supported by observation of the molecular ion in the mass spectrum which displays the appropriate isotopic distribution.

\section{Rhenium vinylidenes and cumulenes}

In view of the activity of compounds containing $\mathrm{Re}=\mathrm{C}$ bonds in alkene metathesis catalysis, the formation of vinylidene and cumulene complexes supporting rhenium-carbon multiple bonds stabilised by the macrocyclic triphosphine has been studied.

Abstraction of halide from $2^{i \mathrm{Bu}}$ using silver triflate or trimethylsilyl triflate followed by reaction with a terminal acetylene results in the formation of a vinylidene complex $\left(4^{i \mathrm{Bu}}\right)$ via a 1,2-hydrogen shift. Alternatively, the reaction of the macrocycle hydride complex $3^{i \mathrm{Bu}}$ with $\mathrm{Me}_{3} \mathrm{OBF}_{4}$, followed by addition of the terminal acetylene gives rise to the same material which is isolated as a red powder after work up. The IR spectrum of $4^{\text {iBu }}$ shows an increase in $v(\mathrm{CO})$ in comparison to compound $\mathbf{3}^{i \mathrm{Bu}}$ as might be expected for a cationic complex and the presence of the relatively $\pi$-acidic vinylidene ligands $;{ }^{15}$ bands attributable to the vinylidene $\mathrm{C}=\mathrm{C}$ function $\left(1649 \mathrm{~cm}^{-1}\right)$ and the $\mathrm{OTf}^{-}$counterion $\left(1276 \mathrm{~cm}^{-1}\right)$ are also observed. In the ${ }^{1} \mathrm{H}$ NMR spectrum, the vinylidene proton is split into a quartet $\left(\delta 4.75,{ }^{4} J_{\mathrm{P}-\mathrm{H}}=7.06\right.$ $\mathrm{Hz}$ ) due to coupling to three apparently equivalent phosphines on the NMR timescale. Low energy barriers for ligand rotation have previously been observed for vinylidene compounds. ${ }^{11}$ The ${ }^{31} \mathrm{P}$ NMR spectrum of $4^{\text {Bu }}$ shows an $\mathrm{A}_{2} \mathrm{~B}$ pattern of a doublet and a triplet $\left(\delta-38.1,-31.7\right.$ respectively; $\left.{ }^{2} J_{\mathrm{P}-\mathrm{P}}=28.3 \mathrm{~Hz}\right)$ indicating magnetically inequivalent phosphorus nuclei in a ratio of 
2:1 and that the complex appears stereochemically rigid at ambient temperature under these conditions.

The ${ }^{13} \mathrm{C}\left\{{ }^{1} \mathrm{H}\right\}$ NMR spectrum confirms the presence of a vinylidene ligand (as opposed to a $\pi$-alkyne or $\sigma$-alkynyl ligand), i.e. a resonance attributable to the $\alpha-\mathrm{C}$ bonded to $\mathrm{Re}$ is observed as a broadened singlet at $\delta 352.1$ reflecting unresolved coupling to the inequivalent phosphorus nuclei. The inequivalence of the macrocycle ring is also indicated by the resonances attributable to the ring carbons and P-alkyl substituents. Resonances to attributable to the aromatic and secondary carbons may also be assigned; in addition, the molecular ion is observed in the mass spectrum with the appropriate isotopic distribution.

Allenylidene $(\mathrm{M}=\mathrm{C}=\mathrm{C}-\mathrm{C})$ compounds have been synthesised in a similar manner to the vinylidene complex, $\mathbf{4}^{\mathbf{i B u}}$, using propargyl alcohols. ${ }^{16}$ Addition of silver triflate to a dichloromethane solution of $\mathbf{2}^{\text {i }}$ fullowed by $\mathrm{HC} \equiv \mathrm{CC}(\mathrm{OH}) \mathrm{Ph}_{2}$ leads to directly to the unsaturated cumulene complex $5^{\mathbf{B u}}$, presumably by the allenylidene intermediate $\left\{\left(12\left[a_{n}\right] \mathrm{P}_{3}{ }_{3} \mathrm{Bu}_{3}\right)(\mathrm{CO})_{2} \mathrm{Re}=\mathrm{C}=\right.$ $\left.\mathrm{CHC}(\mathrm{OH}) \mathrm{Ph}_{2}\right\}$ which eliminates water spontaneously and was not observed. $\mathbf{5}^{\mathbf{B} \mathbf{B u}}$ was isolated as a yellow solid after work up. The IR spectrum shows absorptions due to $v(\mathrm{CO})$ at a lower frequency than observed in $4^{\text {iBu }}$ indicating the cumulene ligand to be a better donor than the vinylidene; bands attributable to the $\mathrm{C}=\mathrm{C}$ function $\left(1894 \mathrm{~cm}^{-1}\right)$ and the $\mathrm{OTf}^{-}$anion $\left(1278 \mathrm{~cm}^{-1}\right)$ are also observed. The ${ }^{31} \mathrm{P}\left\{{ }^{1} \mathrm{H}\right\}$ NMR spectrum consists of an $\mathrm{A}_{2} \mathrm{~B}$ pattern of a doublet and a triplet $(\delta-31.4,-48.9$ respectively; ${ }^{2} J_{\mathrm{P}-\mathrm{P}}=30.5 \mathrm{~Hz}$ ) indicating stereochemical rigidity. Again the molecular ion is observed in the mass spectrum with the appropriate $\mathrm{Re}$ isotope pattern.

\section{Manganese}

The manganese bromodicarbonyl analogue of $\mathbf{2}$ is readily prepared by the white-light photolysis of solutions of $\mathrm{Mn}(\mathrm{CO})_{5} \mathrm{Br}$ in the presence of the macrocycle, $12\left[\mathrm{ane}_{3} \mathrm{P}_{3} \mathrm{Et}_{3}\right.$ which gives rise to a yellow crystalline solid for which analytical data indicates the formula (12[ane] $\left.\mathrm{P}_{3} \mathrm{Et}_{3}\right) \mathrm{Mn}(\mathrm{CO})_{2} \mathrm{Br}, 6^{\mathrm{Et}}$. The IR spectrum of $\mathbf{6}^{\mathrm{Et}}$ showed two bands corresponding to a cis-dicarbonyl unit (1907, $\left.1847 \mathrm{~cm}^{-1}\right)$. The ${ }^{31} \mathrm{P}\left\{{ }^{1} \mathrm{H}\right\}$ NMR spectrum consists of a doublet and a triplet $\left(\delta 10.5,58.6\right.$ respectively; $\left.{ }^{2} J_{\mathbf{P}-\mathbf{P}}=48 \mathrm{~Hz}\right)$ corresponding to an $\mathrm{A}_{2} \mathrm{~B}$ spin system; this spectrum is temperature invariant $\left(30\right.$ to $\left.-80{ }^{\circ} \mathrm{C}\right)$ indicating the complex to the steriochemically rigid under these conditions. In the ${ }^{13} \mathrm{C}\left\{{ }^{1} \mathrm{H}\right\}$ NMR spectrum, broadened resonances are observed for the macrocycle carbons and a weak and broadened multiplet may be assigned to the carbonyl carbon resonance ( $\delta 194)$.

The X-ray crystal structure of the manganese compound, $\mathbf{6}^{\mathrm{Et}}$, has been determined and is represented in Fig. 3 along with selected bond lengths and angles. The overall structure is close to octahedral with distortions arising from differences in bond lengths $\left(\mathrm{Mn}-\mathrm{P}_{\mathrm{av}}=2.300(2) \AA, \mathrm{Mn}-\mathrm{C}_{\mathrm{av}}=1.807(8) \AA, \mathrm{Mn}-\mathrm{Br}=\right.$ 2.569(1) $\AA$ ) and deviations from idealised angles $\left(\mathrm{P}-\mathrm{Mn}-\mathrm{P}_{\mathrm{av}}=\right.$ 93.81(7) $\left.)^{\circ}, \mathrm{P}-\mathrm{Mn}-\mathrm{C}_{\mathrm{av}}=89.4(3)^{\circ}, \mathrm{P}-\mathrm{Mn}-\mathrm{Br}_{\mathrm{av}}=84.59(6)^{\circ}\right)$. These values compare closely with those for other manganese bromocarbonyl phosphine complexes in the literature. For example, in mer, cis, cis- $\left[\mathrm{MnBr}(\mathrm{CO})_{2}\left\{\mathrm{P}(\mathrm{OPh})_{3}\right\}(\mathrm{dppm})\right]$ the corresponding average bond lengths are very similar $(\mathrm{Mn}-\mathrm{P}=2.294(2) \AA$, $\mathrm{Mn}-\mathrm{C}=1.78(6), \mathrm{Mn}-\mathrm{Br}=2.527(1) \AA) .{ }^{17}$

In $6^{\mathrm{Et}}$, the $\mathrm{Mn}-\mathrm{P}$ distances trans to $\mathrm{CO}$ are significantly longer than that trans to $\mathrm{Br}(2.329(2)$ and 2.243(2) A respectively) indicating a stronger trans influence of the $\pi$-acidic $\mathrm{CO}$ ligands in comparison to $\mathrm{Br}$ as is expected.

\section{Reactions with alkenes}

\section{Rhenium and manganese}

In view of the known activity of rhenium carbonyl halides in alkene metathesis, the reactivity of the phosphorus macrocycle

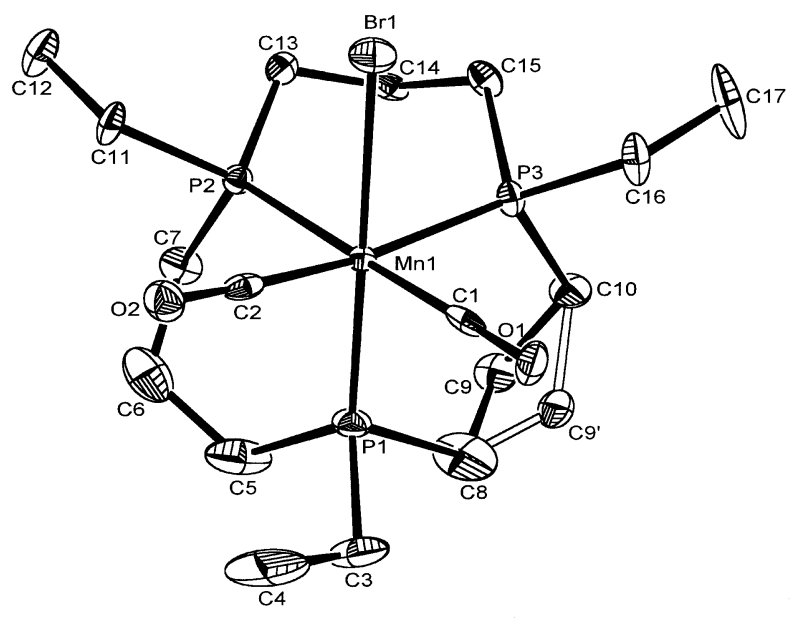

Fig. 3 X-Ray structure of $\left(12[\operatorname{ane}] \mathrm{P}_{3} \mathrm{Et}_{3}\right) \mathrm{Mn}(\mathrm{CO})_{2} \mathrm{Br}, \mathbf{6}^{\mathrm{Et}}$, showing the atom labelling scheme. One position of the disordered $\mathrm{CH}_{2} \mathrm{CH}_{2} \mathrm{CH}_{2}$ bridge is indicated by open bonds. Thermal ellipsoids are drawn at $50 \%$ probability level. Selected bond lengths (A) and angles $\left({ }^{\circ}\right)$ : $\mathrm{Mn}-\mathrm{Br}$ 2.569(1), Mn-C1 1.821(8), Mn-C2 1.793(7), Mn-P2 2.327(2), Mn-P1 2.243(2). Mn-P3 2.331(2); C1-Mn-C2 91.2(3), C1-Mn-P2 178.2(2), C2-Mn-P2 87.8(2), C1-Mn-P1 87.9(2), C2-Mn-P1 93.8(2), P2-MnP1 93.78(6), C1-Mn-P3 88.1(2), C2-Mn-P3 171.1(2), P2-Mn-P3 92.57(7), P1-Mn-P3 95.08(6), C1-Mn-Br1 93.5(2), C2-Mn-Br1 86.8(2), P2-Mn-Br1 84.85(4), P1-Mn-Br1 178.47(6), P3-Mn-Br1 84.32(4).

complexes $\mathbf{2}^{\mathbf{R}}$ and $\mathbf{3}^{\mathrm{R}}$ with cyclic alkenes was studied. Addition of the initiator, ethyl aluminium dichloride to a solution of the chloro complexes (conditions similar to the initiation of the metathesis of 1 -hexene by $\mathrm{Re}(\mathrm{CO})_{5} \mathrm{Cl}^{18}$ ) results in a colour change from colourless through green, to red. Addition of norbornene to this solution results in the strongly exothermic reaction and the evolution of gas whilst the solution becomes increasingly viscous. These reactions proceed at a reasonable rate at $0{ }^{\circ} \mathrm{C}$, however for the collection of comparative data and polymer properties, reactions were performed at $25{ }^{\circ} \mathrm{C}$ (Table 1). For both compounds $2\left(\mathrm{R}=\mathrm{Et}\right.$, $\left.{ }^{\mathrm{i}} \mathrm{Bu}\right)$, a polymeric product is formed by ring opening metathesis polymerisation (ROMP) as indicated by a strong $\mathrm{C}=\mathrm{C}$ stretching frequency in the IR spectrum $\left[v(\mathrm{C}=\mathrm{C})=1645 \mathrm{~cm}^{-1}\right]$. The behaviour of the catalyst is dramatically influenced by the nature of the P-alkyl substituents. Thus, with $\mathbf{2}^{\mathbf{i B u}}$, a low molecular weight polymer is obtained (also with a relatively narrow polydispersity). For the ethyl derivative, $\mathbf{2}^{\mathrm{Et}}$, the catalyst system is more active than for its bulkier analogue and a polymer product with a much higher molecular weight (and also a higher polydispersity) is obtained. Integration of the vinyl protons in the ${ }^{1} \mathrm{H}$ NMR spectrum of this polymer indicates a random distribution of cis and trans substituted double bonds. Addition of 2 equivalents of $\mathrm{EtAlCl}_{2}$ to solutions of $2^{i \mathbf{B u}}$ again gives rise to red solutions which show two bands attributable to $v(C O)\left(1981,1917 \mathrm{~cm}^{-1}\right)$ in the IR spectrum and which are consistent with the presence of $c i s$ carbonyls. In addition, the reaction of $2^{i \mathbf{B u}}$ with MeLi does not result in any colour change and the starting complex may be recovered unchanged from the residue. These observations support a mechanism of activation based upon the formation of alkylidenes by substitution of the rhenium halide followed by $\alpha$-hydride abstraction, as has been proposed for the metathesis catalyst system derived from $\mathrm{WCl}_{6}$ and $\mathrm{EtAlCl}_{2} .{ }^{19}$ The vinylidene and cumulene complexes, $\mathbf{4}^{\mathbf{B B u}}$ and $\mathbf{5}^{\mathbf{B} \mathbf{B u}}$, are inactive in the presence of a suitable initiator, presumably due to the absence of labile ligands at the metal preventing coordination of substrate alkenes.

The manganese complexes, $\mathbf{6}^{\mathrm{Et}}$, is also active in ROMP under similar conditions. For $\mathbf{6}^{\mathrm{Et}}$, the activity of the catalyst is similar to that of the rhenium analogue $\left(2^{\mathrm{Et}}\right)$ although the molecular weight of the polymer is very substantially lower. ${ }^{13} \mathrm{C}$ NMR and 
Table 1 Polymerisation data for Re, Mn and Ru complexes.

\begin{tabular}{|c|c|c|c|c|c|c|c|}
\hline Complex/mmol & Monomer (g) & Initiator & $\begin{array}{l}\text { Solvent } \\
\text { (temp. } /{ }^{\circ} \mathrm{C} \text { ) }\end{array}$ & $\begin{array}{l}\text { Yield } \\
(\mathrm{g}, \%)\end{array}$ & $\begin{array}{l}\text { Activity } \\
\left(\mathrm{kg} \mathrm{P} \mathrm{mol}^{-1}\right)\end{array}$ & $M_{\mathrm{w}}$ & PDi \\
\hline$\left(12[\right.$ ane $\left.] \mathrm{P}_{3}{ }^{i} \mathrm{Bu}_{3}\right) \operatorname{Re}(\mathrm{CO})_{2} \mathrm{Cl}\left(2^{\mathrm{iBu}}\right)(0.03)$ & Norbornene (1.00) & $\mathrm{EtAlCl}_{2}(4: 1)$ & $\mathrm{CH}_{2} \mathrm{Cl}_{2}(25)$ & $0.875,87 \%$ & 11.8 & 510 & 1.6 \\
\hline$\left(12[\right.$ ane $\left.] \mathrm{P}_{3} \mathrm{Et}_{3}\right) \operatorname{Re}(\mathrm{CO})_{2} \mathrm{Cl}\left(2^{\mathrm{Et}}\right)(0.015)$ & Norbornene $(0.50)$ & $\mathrm{EtAlCl}_{2}(4)$ & $\mathrm{CH}_{2} \mathrm{Cl}_{2}(25)$ & $0.495,98 \%$ & 14.6 & 217,500 & 5 . \\
\hline$\left(12[\right.$ ane $\left.] \mathrm{P}_{3} \mathrm{Et}_{3}\right) \mathrm{Mn}(\mathrm{CO})_{2} \mathrm{Br}\left(6^{\mathrm{Et}}\right)(0.02)$ & Norbornene $(0.50)$ & $\operatorname{EtAlCl}_{2}(4: 1)$ & $\mathrm{CH}_{2} \mathrm{Cl}_{2}(25)$ & $0.30,60 \%$ & 12.6 & 3710 & 2.9 \\
\hline$\left(12[\right.$ ane $\left.] \mathrm{P}_{3} \mathrm{Et}_{3}\right)-\mathrm{RuCl}_{2} \mathrm{dmso}(0.035)$ & Norbornene $(0.55)$ & $\mathrm{EtAlCl}_{2}(4: 1)$ & $\mathrm{CH}_{2} \mathrm{Cl}_{2}(25)$ & $0.137,25 \%$ & 13.2 & 10,400 & 6.4 \\
\hline$\left(12[\right.$ ane $\left.] \mathrm{P}_{3} \mathrm{Et}_{3}\right)-\mathrm{RuCl}_{2} \mathrm{dmso}(0.09)$ & Norbornadiene (1.0) & $\mathrm{EtAlCl}_{2}(4: 1)$ & $\mathrm{CH}_{2} \mathrm{Cl}_{2}(25)$ & $0.871,87 \%$ & 9.67 & 188,000 & 67 \\
\hline$\left(12[\right.$ ane $\left.] \mathrm{P}_{3} \mathrm{Et}_{3}\right) \mathrm{RuCl}_{2} \mathrm{dmso}(0.072)$ & Norbornene $(0.50)$ & $\mathrm{TMSCHN}_{2} / \operatorname{AgOTf}(2)$ & $\mathrm{C}_{6} \mathrm{H}_{5} \mathrm{Cl}(120)$ & $0.12,24 \%$ & 1.67 & 56300 & 2.3 \\
\hline
\end{tabular}

${ }^{1} \mathrm{H}$ NMR data imply the polymer to be atactic with respect to the double bond geometry. To our knowledge, this is the first example of a manganese compound active in ROMP catalysis Also of interest are comparisons of the product polymer complexes and activity of the catalysts between ligands of different bulk and metals of different sizes; thus, the combination of the least sterically demanding macrocycle and the largest metal gives rise to the most active catalyst and the highest molecular weight polymer. Clearly steric factors radically influence the catalytic behaviour, higher molecular weight products being favoured by a more open and easily accessible metal centre.

\section{Ruthenium}

The well known Grubbs' catalyst, $\mathrm{Cl}_{2} \mathrm{Ru}(=\mathrm{CHPh})\left(\mathrm{PR}_{3}\right)_{2}$, has been extensively studied and modified, for example replacing the phosphines with $\mathrm{N}$-heterocyclic carbenes, ${ }^{20}$ or changing the benzylidene for a vinylidene ${ }^{21}$ or allenylidene ${ }^{22}$ moiety. The original $\mathrm{Ru}(\mathrm{II})$ complex has a trigonal bipyramidal structure and the more basic $\mathrm{PCy}_{3}$ phosphine is more active than $\mathrm{PPh}_{3}$ It is of interest to compare the behaviour of the known catalytically active complexes with that of the $\mathrm{d}^{6}$ octahedral $\mathrm{Ru}(\mathrm{II})$ macrocycle compound, (12[ane $\left.] \mathrm{P}_{3} \mathrm{Et}_{3}\right) \mathrm{RuCl}_{2}(\mathrm{dmso}), 7^{\mathrm{Et}} \cdot{ }^{4 a}$ Addition of $\mathrm{EtAlCl}$ to solutions of $7^{\mathrm{Et}}$ in $\mathrm{CH}_{2} \mathrm{Cl}_{2}$ causes a colour change from yellow to orange, subsequent addition of norbornene results in a further colour change to red and the solutions very quickly became viscous as poly(vinylcyclopentene) is formed. This activity is similar to that of the rhenium and manganese complexes; the yield decreases with increasing temperature and $7^{\mathrm{Et}}$ is inactive in the absence of the initiator. Using trimethylsilyldiazomethane and silver triflate as the initiator, no reaction was observed with norbornene in $\mathrm{CH}_{2} \mathrm{Cl}_{2}$ but in refluxing chlorobenzene a polymer was formed. Presumably the methyl-substituted carbene is thermally more sensitive than the trimethylsilyl substituted carbene formed from trimethylsilyldiazomethane. The polymers produced by the two routes were also different in their physical properties. The catalyst formed by initiation with $\mathrm{EtAlCl}$ gives a polymer which is soluble in chloroform and has a relatively low molecular weight and high polydispersity, the catalyst formed by initiation with trimethylsilyldiazomethane and silver triflate has a lower activity and the polymer formed is insoluble in chloroform (GPC analysis was performed by dissolution in boiling 1,2-dichlorobenzene) but it has a significantly higher molecular weight and narrower polydispersity. The ${ }^{13} \mathrm{C}$ NMR spectrum of this latter polymer product shows a bias towards trans-trans stereochemistry.

There have been other studies using tridentate donors in the coordination sphere of Grubbs' catalyst. Using the Tp ligand gives the complex $\mathrm{Tp}\left(\mathrm{PCy}_{3}\right)(\mathrm{Cl}) \mathrm{Ru}=\mathrm{CHPh}$ which is inactive for alkene metathesis. ${ }^{23}$ The authors explain this lack of activity by the inability of any ligand to dissociate and form a vacant site however the complex $\mathrm{Tp}(\mathrm{Cl})\left(\mathrm{PPh}_{3}\right) \mathrm{Ru}=\mathrm{C}=\mathrm{CHPh}$ is active under similar conditions and gives high yields of polymer $\left(99 \%, M_{\mathrm{n}}=\right.$ $\left.5.9 \times 10^{4}, \mathrm{PDi}=5.0\right)$ although relatively slowly $\left(72 \mathrm{~h}\right.$ at $\left.40{ }^{\circ} \mathrm{C}\right) .{ }^{24}$ The macrocycle $9[$ ane $] \mathrm{S}_{3}$ has also been used in ROMP reactions. The compound $9[$ ane $\left.] \mathrm{S}_{3} \mathrm{Ru}(=\mathrm{CHPh})\left(\mathrm{PCy}_{3}\right) \mathrm{Cl}\right]^{+}$does ring-open norbornene giving rise to good yields of polymer after $2 \mathrm{~h}$ at room temperature $\left(92 \%, M_{\mathrm{n}}=2.7 \times 10^{5}, \mathrm{PDi}=3.5\right)$ and the authors suggest that ligand dissociation occurs before alkene coordination. ${ }^{25}$ The performance of these complexes (quoted as yields by the authors) indicate that our $\mathrm{Re}$ and $\mathrm{Ru}$ compounds compare very favourably with literature values, indeed $\mathbf{1}^{\mathrm{Et}}$ appears to be significantly more effective as it polymerises norbornene in excellent yield (Table 1) but in shorter timescales $(1 \mathrm{~h})$ and under milder conditions $\left(0^{\circ} \mathrm{C}\right)$.

The path of this reaction is intriguing because the accepted mechanism for Grubbs' catalyst involves phosphine dissociation and subsequent alkene coordination to the resultant vacant site ${ }^{26}$ which helps explain the high activities observed with bulky phosphines. A recent report using the chelating dtbpm ligand $\left(\mathrm{dtbpm}={ }^{\mathrm{t}} \mathrm{Bu}_{2} \mathrm{PCH}_{2} \mathrm{P}^{\mathrm{t}} \mathrm{Bu}_{2}\right)$ also shows high activities in the ring opening of cycloalkenes; ${ }^{27}$ the geometry of the ligand imposes cis coordination of the phosphines but the $\mathrm{Ru}$ complex is square pyramidal and the high activity has been attributed to halide dissociation. By the use of the facially capping macrocycle, the octahedral metal centre must hold the carbene and the alkene cis. Detailed kinetic studies were not performed; from the NMR measurements however, observations relevant to mechanistic considerations can be made. Firstly, there is no evidence of phosphine dissociation in $7^{\mathrm{Et}}$ as there is a temperature invariant (to $-60{ }^{\circ} \mathrm{C}$ ) singlet in the ${ }^{31} \mathrm{P}\left\{{ }^{1} \mathrm{H}\right\}$ NMR spectrum; this behaviour being previously commented on ${ }^{4 a}$ and is consistent with facile dmso ligand exchange processes. ${ }^{28}$ Phosphine dissociation in macrocycle complexes of this nature would also be expected to be restricted in comparison to acyclic or monodentate phosphine ligands. The complex has 18 electrons so an associative mechanism is unlikely and free dmso was observed by ${ }^{1} \mathrm{H}$ and ${ }^{13} \mathrm{C}$ NMR spectroscopy, indicating that it is labile under the reaction conditions and capable of generating available coordination sites required in active species. Unfortunately, a resonance due to the propagating carbene in the ${ }^{1} \mathrm{H}$ NMR spectrum was not observed (as in other examples), ${ }^{29}$ neither was the formation of a metallacycle on addition of one equivalent of monomer.

\section{Experimental}

All reactions were carried out in an atmosphere of dry nitrogen or argon passed through a $\mathrm{CrO}$ (supported on silica) column using standard Schlenk techniques or in a Vacuum Atmospheres glove box. All solvents were dried by refluxing over standard drying agents and distilled immediately prior to use. The light petroleum used had a boiling point range of 40-60 ${ }^{\circ} \mathrm{C}$. The compounds $12[\mathrm{ane}] \mathrm{P}_{3} \mathrm{Et}_{3},{ }^{30} 7^{\mathrm{Et}},{ }^{4 a} \mathrm{ReCl}_{3}(\mathrm{MeCN})-$ $\left(\mathrm{PPh}_{3}\right)_{3},{ }^{31} \operatorname{Re}(\mathrm{CO})_{5} \mathrm{Br},{ }^{32} \operatorname{Re}(\mathrm{CO})_{3}\left(\mathrm{PPh}_{3}\right)_{2} \mathrm{Cl},{ }^{33}$ were prepared by literature methods. All other chemicals were obtained from commercial sources and where appropriate, dried over molecular sieves and deoxygenated by repeated freeze-thaw degassing or recrystallised. Photolyses were carried out using a Hanovia $125 \mathrm{~W}$ mercury discharge lamp $(254 \mathrm{~nm})$ or a $100 \mathrm{~W}$ incandescent tungsten filament lamp as indicated. NMR spectra were recorded on a Bruker DPX-400 instrument at $400 \mathrm{MHz}\left({ }^{1} \mathrm{H}\right)$ and $100 \mathrm{MHz}\left({ }^{13} \mathrm{C}\right)$ or a JEOL FX-90Q at 36.23 $\mathrm{MHz}\left({ }^{31} \mathrm{P}\right)$ or a JEOL Lamda Eclipse 300 at $121.65 \mathrm{MHz}\left({ }^{31} \mathrm{P}\right)$, $300.52 \mathrm{MHz}\left({ }^{1} \mathrm{H}\right)$ and $75.57 \mathrm{MHz}\left({ }^{13} \mathrm{C}\right)$, or a Bruker AMX-360 
at $145.78 \mathrm{MHz}\left({ }^{31} \mathrm{P}\right)$. All chemical shifts are quoted in units of $\delta$ (ppm). ${ }^{1} \mathrm{H}$ and ${ }^{13} \mathrm{C}$ NMR chemical shifts are relative to solvent resonances, ${ }^{31} \mathrm{P}$ chemical shifts are relative to $85 \%$ external $\mathrm{H}_{3} \mathrm{PO}_{4}(\delta=0)$. For ${ }^{13} \mathrm{C}$ assignments see Fig. 2. Magnetic susceptibilities were determined by Evans' method ${ }^{34}$ or by the Gouy method on a Johnson Matthey magnetic susceptibility balance; an experimental diamagnetic correction was measured for $12[$ ane $] \mathrm{P}_{3} \mathrm{R}_{3}$ and applied. Mass spectra (EI and APCI) were recorded on a VG Platform II Fisons mass spectrometer. Infrared spectra were recorded on a Perkin Elmer 1600 or a Nicolet 510 FT-IR spectrometer as a CsI disk or in solution using $\mathrm{KBr}$ solution cells. NMR simulations were carried out using gNMR. ${ }^{35}$ Molecular weight determinations were carried out in chloroform or 1,2-dichlorobenzene solution by RAPRA Technologies Ltd. using a PLgel $2 \times$ mixed bed-D, $30 \mathrm{~cm}, 5 \mu \mathrm{m}$ column at $40{ }^{\circ} \mathrm{C}$ and a flow rate of $1.0 \mathrm{ml} \mathrm{min}^{-1}$ (nominal) and using a refractive index (and differential pressure) detector. The GPC system used was calibrated with polystyrene and the results are expressed as the "polystyrene equivalent" molecular weights. Cyclic voltammetry was performed on a Windsor PGstat 12 potentiostat in $\mathrm{CH}_{2} \mathrm{Cl}_{2}$ with $\mathrm{Bu}_{4} \mathrm{NPF}_{6}(0.1 \mathrm{M})$ supporting electrolyte vs. a $\mathrm{Ag} / \mathrm{Ag}^{+}$reference electrode and $\mathrm{Fc} / \mathrm{Fc}^{+}$internal reference $(0.46 v s$. SCE); data were processed on a PC operating an Autolab program. The labelling scheme for NMR assignments for compounds $2^{\mathrm{R}}, \mathbf{3}^{i \mathrm{Bu}}, \mathbf{4}^{\mathbf{B u}}$, and $\mathbf{5}^{\mathrm{iBu}}$ is defined in Fig. 4.

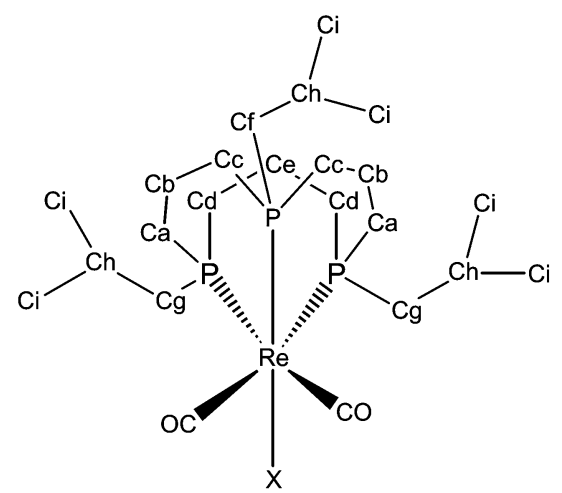

Fig. 4 Labelling scheme for NMR assignments for Re(I) compounds.

\section{X-Ray crystallography}

Crystals suitable for X-ray structure determination were mounted in silicone oil. X-Ray intensity data were recorded on a Bruker-Nonius CCD area detector (compound $\mathbf{1}^{\mathbf{i B u}}, \mathrm{Re}$ ) and a FAST area detector (compound $\mathbf{6}, \mathrm{Mn}$ ) by using monochromated Mo-K $\alpha$ radiation $(\lambda=0.71073 \AA)$ and following previously described procedures. ${ }^{36}$ The data sets were corrected for absorption effects using SORTAV ${ }^{37}$ and DIFABS ${ }^{38}$ for compounds $\mathbf{1}^{\mathrm{iBu}}$ and $\mathbf{6}$, respectively.

The structures were solved by direct methods (SHELXS97) ${ }^{39}$ and refined by full-matrix least squares (SHELX-97) ${ }^{40}$ on $F^{2}$ using all unique data. The $\operatorname{Re}(1), \mathrm{Cl}(1), \mathrm{C}(10), \mathrm{C}(12)$ and $\mathrm{C}(13)$ atoms of the $-\mathrm{CH}_{2} \mathrm{CHMe}_{2}$ group on $\mathrm{P}(2)$ in compound $\mathbf{1}^{i \mathrm{Bu}}$ were located on a mirror plane of symmetry; the $\mathrm{C}(11)$ atom of this group was located off the mirror plane. The unique $\mathrm{P}(1)\left(\mathrm{CH}_{2}\right)_{3} \mathrm{P}(2)$ bridge in this compound was also disordered with atom $\mathrm{C}(5)$ occupying two half-occupied positions. The $\mathrm{P}$ $\mathrm{C}$ and $\mathrm{C}-\mathrm{C}$ distances in the disordered groups were constrained to remain at 1.83 and $1.53 \AA$, respectively. In compound $\mathbf{6}$, the $\mathrm{P}(1)\left(\mathrm{CH}_{2}\right)_{3} \mathrm{P}(3)$ bridge was disordered and the $\mathrm{C}(9)$ and $\mathrm{C}\left(9^{\prime}\right)$ atoms were refined with 70 and $30 \%$ site occupancies respectively. All non-hydrogen atoms were anisotropic in both structures, but an ISOR $=0.005$ constraint was applied for the atoms $\mathrm{C}(1), \mathrm{C}(9)$ and $\mathrm{C}\left(9^{\prime}\right)$ in $\mathbf{6}$. The hydrogen atoms on the $\mathrm{C}(4)$ and $\mathrm{C}(5)$ atoms of the disordered chain and the $\mathrm{C}(10)$ $\mathrm{C}(13)$ atoms of the $-\mathrm{CH}_{2} \mathrm{CHMe}_{2}$ group in $\mathbf{1}^{\mathrm{iBu}}$ and those on the
$\mathrm{C}(8)-\mathrm{C}(10)$ atoms of the disordered chain in $\mathbf{6}$ were ignored. Other hydrogen atoms were included in calculated positions (riding model). Compound 6 was refined as a 48/52\% racemic twin. Details of crystal data and refinement parameters are given in Table 2.

CCDC reference numbers 153078 and 187745.

See http://www.rsc.org/suppdata/dt/b2/b205754a/ for crystallographic data in CIF or other electronic format.

\section{2[ane] $\mathbf{P}_{3}{ }^{i} \mathrm{Bu}_{3} \mathbf{R e C l}_{3}, \mathbf{1}^{i \mathrm{Bu}}$}

To $\mathrm{ReCl}_{3}(\mathrm{MeCN})\left(\mathrm{PPh}_{3}\right)_{2}(0.066 \mathrm{~g}, 0.77 \mathrm{mmol})$ dissolved in $\mathrm{CH}_{2} \mathrm{Cl}_{2}\left(10 \mathrm{~cm}^{3}\right)$ was added $12[\mathrm{ane}] \mathrm{P}_{3}{ }^{i} \mathrm{Bu}_{3}(0.03 \mathrm{~g} 0.77 \mathrm{mmol})$ and this was heated to reflux for $3 \mathrm{~h}$ to give a dark green solution. The solvent was removed in vacuo and the resulting sticky green solid washed with light petroleum $\left(5 \times 30 \mathrm{~cm}^{3}\right)$. The green powder was redissolved in $\mathrm{CH}_{2} \mathrm{Cl}_{2}\left(3 \mathrm{~cm}^{3}\right)$ and light petroleum $\left(5 \mathrm{~cm}^{3}\right)$ added. After cooling to $-30{ }^{\circ} \mathrm{C}$ the resultant green microcrystals were isolated by filtration and dried in vacuo. Yield, $0.33 \mathrm{~g}(68 \%)$. Crystals suitable for X-Ray diffraction were grown by slow evaporation of a $\mathrm{CD}_{2} \mathrm{Cl}_{2}$ solution (Found: $\mathrm{C}$, 36.4; $\mathrm{H}, 6.35 . \mathrm{C}_{21} \mathrm{H}_{45} \mathrm{Cl}_{3} \mathrm{P}_{3} \mathrm{Re}$ requires: $\left.\mathrm{C}, 36.93 ; \mathrm{H}, 6.64 \%\right) .{ }^{1} \mathrm{H}$ NMR $\left(\mathrm{CD}_{2} \mathrm{Cl}_{2}\right): \delta 18.1$ (br, 3H, $\left.\mathrm{PCH}_{2} \mathrm{CH}_{2} \mathrm{CH}_{2} \mathrm{P}\right) ; 9.3(\mathrm{~m}, 3 \mathrm{H}$, $\mathrm{PCH}_{2} \mathrm{CH}_{2} \mathrm{CH}_{2} \mathrm{P}$ ); 8.8 (br, 3H, $\mathrm{PCH}_{2} \mathrm{CH}\left(\mathrm{CH}_{3}\right)_{2}$ ); 4.75 (br, $6 \mathrm{H}$, $\left.\mathrm{PCH}_{2} \mathrm{CH}_{2} \mathrm{CH}_{2} \mathrm{P}\right) ; 2.8\left(\mathrm{~d},{ }^{2} \mathrm{~J}_{\mathrm{HH}}=7 \mathrm{~Hz}, 18 \mathrm{H}, \mathrm{PCH}_{2} \mathrm{CH}\left(\mathrm{CH}_{3}\right)_{2}\right)$; $-1.1\left(\mathrm{~m}, 6 \mathrm{H}, \mathrm{PCH}_{2} \mathrm{CH}_{2} \mathrm{CH}_{2} \mathrm{P}\right) ;-4.2\left(\mathrm{~m}, 6 \mathrm{H}, \mathrm{PCH}_{2} \mathrm{CH}\left(\mathrm{CH}_{3}\right)_{2}\right)$. ${ }^{13} \mathrm{C}$ NMR $\left(\mathrm{CD}_{2} \mathrm{Cl}_{2}\right): \delta 42.0\left(\mathrm{PCH}_{2} \mathrm{CH}\left(\mathrm{CH}_{3}\right)_{2}\right)$. IR (CsI disk, $\mathrm{cm}^{-1}$ ): 2959 (s), 1482 (s), 1434 (s), 1363 (m), 1261 (m), 1187 (w), $1162(\mathrm{~m}), 1092$ (s), 1068 (m), $1026(\mathrm{~m}), 801(\mathrm{~m}), 746(\mathrm{sh}), 696$ (sh), 519 (sh), 497 (m), 461 (s), 347 (w), 308 (m). $\mu_{\text {eff }}=1.42 \mu_{\mathrm{B}}$. MS (APCI): $681.1\left(\mathrm{M}^{+}\right.$, correct isotope distribution for ${ }^{185 / 187} \mathrm{Re}$ and $\left.{ }^{35 / 37} \mathrm{Cl}\right), 647.65(\mathrm{M}-\mathrm{Cl}), 612.2\left(\mathrm{M}^{+}-2 \mathrm{Cl}\right)$.

\section{2[ane]P ${ }_{3}^{i} \mathrm{Bu}_{3} \operatorname{Re}(\mathrm{CO})_{2} \mathrm{Cl}, 2^{i \mathrm{Bu}}$}

To sodium amalgam $(0.007 \mathrm{~g} \mathrm{Na}, 0.31 \mathrm{mmol})$ suspended in THF $\left(25 \mathrm{~cm}^{3}\right)$ was added $\mathbf{1}^{\text {iBu }}(0.096 \mathrm{~g}, 0.15 \mathrm{mmol})$ as a solid. The $\mathrm{N}_{2}$ atmosphere was removed in vacuo and the flask backfilled with $\mathrm{CO}(1 \mathrm{~atm})$. This was stirred for $5 \mathrm{~h}$ to give a colourless solution that was filtered through a short plug of Celite, concentrated to $2 \mathrm{~cm}^{3}$ and diluted with light petroleum $\left(3 \mathrm{~cm}^{3}\right)$. On cooling to $-30^{\circ} \mathrm{C}$ a yellow powder was obtained which was washed with light petroleum $\left(2 \times 5 \mathrm{~cm}^{3}\right)$ and dried in vacuo. Yield, $0.099 \mathrm{~g}(96 \%)$ (Found: C, 40.9; $\mathrm{H}, 6.55 . \mathrm{C}_{23} \mathrm{H}_{45} \mathrm{O}_{2} \mathrm{ClP}_{3} \mathrm{Re}$ requires: $\mathrm{C}, 41.34 ; \mathrm{H}, 6.79 \%) .{ }^{31} \mathrm{P}\left\{{ }^{1} \mathrm{H}\right\} \mathrm{NMR}\left(\mathrm{CD}_{2} \mathrm{Cl}_{2}\right): \delta-8.72$ $(\mathrm{t}),-26.43\left(\mathrm{~d}, J_{\mathrm{P}-\mathrm{P}}=19.5 \mathrm{~Hz}\right) .{ }^{1} \mathrm{H} \mathrm{NMR}\left(\mathrm{CD}_{2} \mathrm{Cl}_{2}\right): \delta 0.95(\mathrm{~m}, 18$ $\left.\mathrm{H}, \mathrm{CH}\left(\mathrm{CH}_{3}\right)_{2}\right) ; 1.5-2.3\left(\mathrm{~m}, 27 \mathrm{H}, \mathrm{PCH}_{2} \mathrm{CH}_{2} \mathrm{CH}_{2} \mathrm{P}, \mathrm{PCH}_{2} \mathrm{CH}_{2}-\right.$ $\left.\mathrm{CH}_{2} \mathrm{P}, \mathrm{PCH} \mathrm{H}_{2} \mathrm{CH}\left(\mathrm{CH}_{3}\right)_{2}, \mathrm{PCH}_{2} \mathrm{CH}\left(\mathrm{CH}_{3}\right)_{2}\right) .{ }^{13} \mathrm{C} \mathrm{NMR}\left(\mathrm{CD}_{2} \mathrm{Cl}_{2}\right)$ : $\delta 19.84\left(\mathrm{~s}, \mathrm{C}_{\mathrm{e}}\right) ; 20.73\left(\mathrm{~s}, \mathrm{C}_{\mathrm{b}}\right) ; 22.27\left(\mathrm{t},{ }^{1} J_{\mathrm{PC}}=13.5 \mathrm{~Hz}, \mathrm{C}_{\mathrm{d}}\right) ; 23.74$ $\left(\mathrm{s}, \mathrm{C}_{\mathrm{i}}\right) ; 24.47\left(\mathrm{~d},{ }^{2} J_{\mathrm{PC}}=4 \mathrm{~Hz}, \mathrm{C}_{\mathrm{h}}\right) ; 25.94\left(\mathrm{t},{ }^{1} J_{\mathrm{PC}}=11.5 \mathrm{~Hz}, \mathrm{C}_{\mathrm{a}}\right.$, $\left.\mathrm{C}_{\mathrm{d}}\right) ; 29.83\left(\mathrm{~d},{ }^{1} J_{\mathrm{PC}}=29 \mathrm{~Hz}, \mathrm{C}_{\mathrm{g}}\right) ; 36.39\left(\mathrm{t},{ }^{1} J_{\mathrm{PC}}=14 \mathrm{~Hz}, \mathrm{C}_{\mathrm{c}}\right) ; 45.10$ $\left(\mathrm{d},{ }^{1} J_{\mathrm{PC}}=35 \mathrm{~Hz}, \mathrm{C}_{\mathrm{f}}\right) ; 198.2\left(\mathrm{~m}, \mathrm{AXX}^{\prime} \mathrm{Y}\right.$ spin system $J_{\mathrm{AX}}=$ $50.0 \mathrm{~Hz}, J_{\mathrm{AX}^{\prime}}=-8.0 \mathrm{~Hz}, J_{\mathrm{AY}}=7.0 \mathrm{~Hz}, J_{\mathrm{XX}^{\prime}}=32.0, J_{\mathrm{XY}}=J_{\mathrm{X}^{\prime} \mathrm{Y}}=$ $0.5 \mathrm{~Hz}$ ). IR (THF soln., $\mathrm{cm}^{-1}$ ): v(CO) 1930 (s), 1865 (s). MS (APCI): $632.1\left(\mathrm{M}^{+}\right.$, correct isotope distribution for $\left.{ }^{185 / 187} \mathrm{Re}\right)$, $568.1(\mathrm{M}-2 \mathrm{CO})$.

\section{2[ane $] \mathrm{P}_{3} \mathrm{Et}_{3} \operatorname{Re}(\mathrm{CO})_{2} \mathrm{Cl}, 2^{\mathrm{Et}}$}

Addition of 12 [ane] $\mathrm{P}_{3} \mathrm{Et}_{3}$ to $\mathrm{ReCl}_{3}(\mathrm{MeCN})\left(\mathrm{PPh}_{3}\right)_{2}$ followed by refluxing for $3 \mathrm{~h}$ in a manner identical to the synthesis of $\mathbf{1}^{\mathrm{i} \mathbf{B u}}$ gave rise to an intractable green precipitate that did not dissolve in solvents with which it did not react. This material is presumably the ethyl analogue of $\mathbf{1}^{\text {iBu }}$, although it was not further characterised. The green solid isolated by filtration, washed with $\mathrm{CH}_{2} \mathrm{Cl}_{2}\left(3 \times 5 \mathrm{~cm}^{3}\right)$ and dried in vacuo. $\left(\mu_{\mathrm{eff}}=1.54 \mu_{\mathrm{B}}\right)$. The subsequent preparation and work-up of $2^{\mathrm{Et}}$ was continued in a manner identical to that of $\mathbf{2}^{\mathbf{B} u}$. The yellow product was isolated in $65 \%$ overall yield [based on $\mathrm{ReCl}_{3}(\mathrm{MeCN})\left(\mathrm{PPh}_{3}\right)_{2}$ ] (Found: $\mathrm{C}, 35.3 ; \mathrm{H}, 5.84 . \mathrm{C}_{17} \mathrm{H}_{33} \mathrm{O}_{2} \mathrm{ClP}_{3}$ Re requires: $\mathrm{C}, 34.96 ; \mathrm{H}$, $5.70 \%) .{ }^{31} \mathrm{P}\left\{{ }^{1} \mathrm{H}\right\}$ NMR $\left(\mathrm{CD}_{2} \mathrm{Cl}_{2}\right): \delta-8.09(\mathrm{t}),-25.39\left(\mathrm{~d}, J_{\mathrm{PP}}=\right.$ 
Table 2 Crystallographic data for $12\left[\operatorname{ane}_{\mathrm{P}} \mathrm{P}_{3}{ }^{i} \mathrm{Bu}_{3} \mathrm{ReCl}_{3}, \mathbf{1}^{\mathrm{i} \mathrm{Bu}}\right.$ and $12[\operatorname{ane}] \mathrm{P}_{3} \mathrm{Et}_{3} \mathrm{Mn}(\mathrm{CO})_{2} \mathrm{Br}, \mathbf{6}^{\mathrm{Et}}$

\begin{tabular}{|c|c|c|}
\hline Complex & $1^{i B u}$ & $6^{\mathrm{Et}}$ \\
\hline Empirical formula & $\mathrm{C}_{21} \mathrm{H}_{45} \mathrm{Cl}_{3} \mathrm{P}_{3} \mathrm{Re}$ & $\mathrm{C}_{17} \mathrm{H}_{33} \mathrm{BrMnO}_{2} \mathrm{P}_{3}$ \\
\hline Formula weight & 683.03 & 497.19 \\
\hline Temperature/K & $150(2)$ & $150(2)$ \\
\hline Wavelength $/ \AA$ & 0.71073 & 0.71073 \\
\hline Crystal system & Orthorhombic & Orthorhombic \\
\hline Space group & Pnma & $P 2_{1} 2_{1} 2_{1}$ \\
\hline \multirow[t]{3}{*}{ Unit cell dimensions/Å } & $a=14.409(3)$ & $a=7.962(2)$ \\
\hline & $b=15.947(3)$ & $b=15.473(3)$ \\
\hline & $c=11.737(2)$ & $c=17.228(3)$ \\
\hline Volume/Å & $2696.9(9)$ & 2122.4(8) \\
\hline$Z$ & 4 & 4 \\
\hline$D_{\mathrm{c}} / \mathrm{Mg} \mathrm{m}^{-3}$ & 1.682 & 1.556 \\
\hline Absorption coefficient $/ \mathrm{mm}^{-1}$ & 4.988 & 2.739 \\
\hline$F(000)$ & 1368 & 1024 \\
\hline Crystal size/mm & $0.25 \times 0.20 \times 0.20$ & $0.18 \times 0.15 \times 0.12$ \\
\hline$\theta$ Range (data collection) $/^{\circ}$ & $2.24-25.35$ & $1.77-24.90$ \\
\hline Index ranges & $-17 \leqslant h<0,-19 \leqslant k \leqslant 0,-14 \leqslant 1 \leqslant 14$ & $-9 \leqslant h \leqslant 8,-14 \leqslant k \leqslant 17,-17 \leqslant 1 \leqslant 20$ \\
\hline Reflections collected & 9845 & 9181 \\
\hline Independent reflections & $2556[R(\mathrm{int})=0.2675]$ & $3279[R(\mathrm{int})=0.0928]$ \\
\hline Max. and min. transmission & 0.4353 and 0.3686 & 0.7346 and 0.6385 \\
\hline Refinement method & Full-matrix least-squares on $F^{2}$ & Full-matrix least-squares on $F^{2}$ \\
\hline Data/restraints/parameters & $2556 / 8 / 151$ & $3279 / 18 / 230$ \\
\hline Goodness-of-fit on $F^{2}$ & 1.004 & 1.006 \\
\hline Final $R$ indices $[I>2 \sigma(I)]$ & $R 1=0.0641, w R 2=0.1492$ & $R 1=0.0360, w R 2=0.0831$ \\
\hline$R$ indices (all data) & $R 1=0.0677, w R 2=0.1508$ & $R 1=0.0430, w R 2=0.0841$ \\
\hline Largest diff. peak and hole/e $\AA^{-3}$ & 4.555 and -4.258 & 0.409 and -0.465 \\
\hline
\end{tabular}

$20.7 \mathrm{~Hz}) .{ }^{1} \mathrm{H}$ NMR $\left(\mathrm{CD}_{2} \mathrm{Cl}_{2}\right): \delta 1.5-2.3\left(\mathrm{~m}, 33 \mathrm{H}, \mathrm{PCH}_{2} \mathrm{CH}_{2}-\right.$ $\left.\mathrm{CH}_{2} \mathrm{P}, \quad \mathrm{PCH}_{2} \mathrm{CH}_{2} \mathrm{CH}_{2} \mathrm{P}, \mathrm{PCH}_{2} \mathrm{CH}_{3}, \mathrm{PCH}_{2} \mathrm{CH}_{3}\right),{ }^{13} \mathrm{C} \quad \mathrm{NMR}$ $\left(\mathrm{CD}_{2} \mathrm{Cl}_{2}\right): \delta 19.91\left(\mathrm{~s}, \mathrm{C}_{\mathrm{e}}\right) ; 21.04\left(\mathrm{~s}, \mathrm{C}_{\mathrm{b}}\right) ; 23.01\left(\mathrm{~s}, \mathrm{C}_{\mathrm{i}}\right) ; 25.21$ $\left(\mathrm{d},{ }^{2} J_{\mathrm{PC}}=4 \mathrm{~Hz}, \mathrm{C}_{\mathrm{h}}\right) ; 29.91\left(\mathrm{~d},{ }^{1} J_{\mathrm{PC}}=29 \mathrm{~Hz}, \mathrm{C}_{\mathrm{g}}\right) ; 46.80\left(\mathrm{~d},{ }^{1} J_{\mathrm{PC}}=\right.$ $\left.35 \mathrm{~Hz}, \mathrm{C}_{\mathrm{g}}\right) ; 36.42\left(\mathrm{t},{ }^{1} J_{\mathrm{PC}}=14 \mathrm{~Hz}, \mathrm{C}\right) ; 27.12\left(\mathrm{t},{ }^{1} J_{\mathrm{PC}}=11.5 \mathrm{~Hz}\right.$, C); $22.86\left(\mathrm{t},{ }^{1} J_{\mathrm{PC}}=13.5 \mathrm{~Hz}, \mathrm{C}\right) ; 198.5(\mathrm{~m}, \mathrm{CO})$. IR (THF soln., $\left.\mathrm{cm}^{-1}\right): v(\mathrm{CO}) 1926(\mathrm{~s}), 1860(\mathrm{~s})$.

\section{2[ane $] \mathrm{P}_{3}{ }_{3} \mathrm{Bu}_{3} \operatorname{Re}(\mathrm{CO})_{2} \mathrm{H}, 3^{i \mathrm{Bu}} .2^{i \mathrm{Bu}}$}

$(0.17 \mathrm{~g}, 0.02 \mathrm{mmol})$ was dissolved in THF $\left(20 \mathrm{~cm}^{3}\right)$ and cooled to $0{ }^{\circ} \mathrm{C}$ and $\mathrm{LiAlH}_{4}(0.12 \mathrm{~g}, 3.16 \mathrm{mmol})$ added as a solid in several small portions. This was allowed to warm to room temperature and then refluxed overnight. The cooled reaction mixture was filtered and the solvent concentrated to $\sim 5 \mathrm{~cm}^{3}$. Toluene $\left(10 \mathrm{~cm}^{3}\right)$ was added and on cooling to $-30{ }^{\circ} \mathrm{C}$, small white microcrystals formed which were isolated by filtration and dried in vacuo. Yield, $0.16 \mathrm{~g} \mathrm{(91 \% )} \mathrm{(Found:} \mathrm{C,} \mathrm{43.1;} \mathrm{H,} 6.95$. $\mathrm{C}_{23} \mathrm{H}_{46} \mathrm{O}_{2} \mathrm{P}_{3}$ Re requires: C, 43.59; $\left.\mathrm{H}, 7.32 \%\right) .{ }^{31} \mathrm{P}\left\{{ }^{1} \mathrm{H}\right\}$ NMR $\left(\mathrm{CD}_{2} \mathrm{Cl}_{2}\right): \delta-23.69$ (br s). ${ }^{1} \mathrm{H}$ NMR $\left(\mathrm{CD}_{2} \mathrm{Cl}_{2}\right): \delta-6.76\left(\mathrm{t},{ }^{2} J_{\mathrm{PH}}=\right.$ $27.5 \mathrm{~Hz}, 1 \mathrm{H}, \mathrm{ReH}) ; 0.70\left(\mathrm{~m}, 18 \mathrm{H}, \mathrm{CH}_{2} \mathrm{CH}\left(\mathrm{CH}_{3}\right)_{2}\right), 1.2-2.3(\mathrm{~m}$, $27 \mathrm{H}, \quad \mathrm{PCH}_{2} \mathrm{CH}_{2} \mathrm{CH}_{2} \mathrm{P}, \quad \mathrm{PCH}_{2} \mathrm{CH}_{2} \mathrm{CH}_{2} \mathrm{P}, \quad \mathrm{PCH} \mathrm{CH}_{2} \mathrm{CH}\left(\mathrm{CH}_{3}\right)_{2}$, $\left.\mathrm{PCH}_{2} \mathrm{CH}\left(\mathrm{CH}_{3}\right)_{2}\right) .{ }^{13} \mathrm{C}$ NMR $\left(\mathrm{CD}_{2} \mathrm{Cl}_{2}\right): \delta 19.82\left(\mathrm{~s}, \mathrm{C}_{\mathrm{e}}\right) ; 20.72$ $\left(\mathrm{s}, \mathrm{C}_{\mathrm{b}}\right) ; 23.72\left(\mathrm{t},{ }^{1} J_{\mathrm{PC}}=13 \mathrm{~Hz}, \mathrm{C}_{\mathrm{d}}\right) ; 24.18\left(\mathrm{~s}, \mathrm{C}_{\mathrm{i}}\right) ; 24.70\left(\mathrm{~d},{ }^{1} J_{\mathrm{PC}}=\right.$ $\left.4 \mathrm{~Hz}, \mathrm{C}_{\mathrm{h}}\right) ; 28.63\left(\mathrm{t},{ }^{1} J_{\mathrm{PC}}=10 \mathrm{~Hz}, \mathrm{C}_{\mathrm{a}}, \mathrm{C}_{\mathrm{d}}\right) ; 30.05\left(\mathrm{~d},{ }^{1} J_{\mathrm{PC}}=31 \mathrm{~Hz}\right.$, $\left.\mathrm{C}_{\mathrm{g}}\right) ; 36.21\left(\mathrm{t},{ }^{1} J_{\mathrm{PC}}=12 \mathrm{~Hz}, \mathrm{C}_{\mathrm{c}}\right) ; 45.28\left(\mathrm{~d},{ }^{1} J_{\mathrm{PC}}=35 \mathrm{~Hz}, \mathrm{C}_{\mathrm{f}}\right) ; 198.4$ (m, CO). IR (THF soln., $\mathrm{cm}^{-1}$ ): v(CO) 1910 (s), 1845 (s). MS (APCI): $587.6\left(\mathrm{M}^{+}\right.$, correct isotope distribution for $\left.{ }^{185 / 187} \mathrm{Re}\right)$, $533.6(\mathrm{M}-2 \mathrm{CO})$.

\section{$\left[12[\text { ane }] \mathrm{P}_{3}{ }^{i} \mathrm{Bu}{ }_{3} \operatorname{Re}(=\mathrm{C}=\mathrm{CHPh})(\mathrm{CO})_{2}\right]^{+}\left(\mathrm{BF}_{4}\right)^{-}, 4^{i \mathrm{Bu}}$}

Method 1. To a solution of $3^{i \mathrm{Bu}}(0.15 \mathrm{~g}, 0.25 \mathrm{mmol})$ in $\mathrm{CH}_{2} \mathrm{Cl}_{2}$ $\left(20 \mathrm{~cm}^{3}\right)$ at $-78{ }^{\circ} \mathrm{C}$ was added $\mathrm{Me}_{3} \mathrm{OBF}_{4}(0.038 \mathrm{~g}, 0.25 \mathrm{mmol})$ and this was allowed to warm to $0{ }^{\circ} \mathrm{C}$ with stirring to give an orange solution. This was stirred for $10 \mathrm{~min}$, recooled to $-78{ }^{\circ} \mathrm{C}$ and phenylacetylene $(0.07 \mathrm{~g}, 0.76 \mathrm{mmol})$ added. On warming to room temperature, the solution became deep red and was stirred for $2 \mathrm{~h}$. followed by concentration under reduced pressure to $\sim 3 \mathrm{~cm}^{3}$ and addition of light petroleum $\left(10 \mathrm{~cm}^{3}\right)$ to precipitate a red powder. This was isolated by filtration and dried in vacuo. Yield, $0.15 \mathrm{~g}(76 \%)$ (Found: $\mathrm{C}, 45.7 ; \mathrm{H}$, 6.42. $\mathrm{C}_{31} \mathrm{H}_{51} \mathrm{BO}_{2} \mathrm{~F}_{4} \mathrm{P}_{3} \mathrm{Re}$ requires: $\mathrm{C}, 45.32 ; \mathrm{H}, 6.26 \%$ ).
Method 2. To a solution of $\mathbf{2}^{\text {iBu }}(0.20 \mathrm{~g}, 0.32 \mathrm{mmol})$ in $\mathrm{CH}_{2} \mathrm{Cl}_{2}$ $\left(20 \mathrm{~cm}^{3}\right)$ was added silver triflate $(0.081 \mathrm{~g}, 0.32 \mathrm{mmol})$ followed by phenylacetylene $(0.10 \mathrm{~g}, 0.95 \mathrm{mmol})$. This was stirred for $2 \mathrm{~h}$ and the resultant red solution worked up as above. Yield, $0.22 \mathrm{~g}$ $(81 \%) .{ }^{31} \mathrm{P}$ NMR $\left(\mathrm{CD}_{2} \mathrm{Cl}_{2}\right): \delta-38.1\left(\mathrm{~d},{ }^{2} J_{\mathrm{PP}}=28.3 \mathrm{~Hz}\right),-31.7$ $\left(\mathrm{t},{ }^{2} J_{\mathrm{PP}}=28.3 \mathrm{~Hz}\right) .{ }^{1} \mathrm{H} \mathrm{NMR}\left(\mathrm{CD}_{2} \mathrm{Cl}_{2}\right): \delta 7.6\left(\mathrm{~d},{ }^{3} J_{\mathrm{HH}}=6.04 \mathrm{~Hz}\right)$, $7.25(\mathrm{~m}), 6.95\left(\mathrm{~d},{ }^{3} J_{\mathrm{HH}}=7.34 \mathrm{~Hz}, 5 \mathrm{H}, \mathrm{Re}=\mathrm{C}=\mathrm{CHPh}\right) ; 4.75(\mathrm{q}$, $\left.{ }^{4} J_{\mathrm{P}-\mathrm{H}}=7.06 \mathrm{~Hz}, 1 \mathrm{H}, \mathrm{Re}=\mathrm{C}=\mathrm{CHPh}\right) ; 0.95\left(\mathrm{~m}, 18 \mathrm{H}, \mathrm{CH}\left(\mathrm{CH}_{3}\right)_{2}\right)$, 1.05-2.2 (m, $27 \mathrm{H}, \mathrm{PCH}_{2} \mathrm{CH}_{2} \mathrm{CH}_{2} \mathrm{P}, \mathrm{PCH}_{2} \mathrm{CH}_{2} \mathrm{CH}_{2} \mathrm{P}, \mathrm{PCH}_{2}-$ $\left.\mathrm{CH}\left(\mathrm{CH}_{3}\right)_{2}, \mathrm{PCH}_{2} \mathrm{CH}\left(\mathrm{CH}_{3}\right)_{2}\right),{ }^{13} \mathrm{C} \mathrm{NMR}\left(\mathrm{CD}_{2} \mathrm{Cl}_{2}\right): \delta 19.82(\mathrm{~s}$, $\left.\mathrm{C}_{\mathrm{e}}\right) ; 20.72\left(\mathrm{~s}, \mathrm{C}_{\mathrm{b}}\right) ; 23.72\left(\mathrm{t},{ }^{1} J_{\mathrm{PC}}=13 \mathrm{~Hz}, \mathrm{C}_{\mathrm{d}}\right) ; 24.18\left(\mathrm{~s}, \mathrm{C}_{\mathrm{i}}\right) ; 24.70$ $\left(\mathrm{d},{ }^{1} J_{\mathrm{PC}}=4 \mathrm{~Hz}, \mathrm{C}_{\mathrm{h}}\right) ; 28.63\left(\mathrm{t},{ }^{1} J_{\mathrm{PC}}=10 \mathrm{~Hz}, \mathrm{C}_{\mathrm{a}}, \mathrm{C}_{\mathrm{d}}\right) ; 30.05(\mathrm{~d}$, $\left.{ }^{1} J_{\mathrm{PC}}=31 \mathrm{~Hz}, \mathrm{C}_{\mathrm{g}}\right) ; 36.21\left(\mathrm{t},{ }^{1} J_{\mathrm{PC}}=12 \mathrm{~Hz}, \mathrm{C}_{\mathrm{c}}\right) ; 45.28\left(\mathrm{~d},{ }^{1} J_{\mathrm{PC}}=\right.$ $\left.35 \mathrm{~Hz}, \mathrm{C}_{\mathrm{f}}\right), 125.2,127.6,128.1,128.2(\mathrm{Ar}) ; 131.2(\mathrm{~s}, \mathrm{Re}=\mathrm{C}=$ $C \mathrm{HPh}) ; 352.1$ (br s, $\mathrm{Re}=C=\mathrm{CHPh}) . \mathrm{IR}\left(\mathrm{KBr} \operatorname{disc~cm}{ }^{-1}\right): v(\mathrm{CO})$ 2000, 1937; $v$ (CC) 1649, $v$ (SO) 1276. MS (APCI): $699.8\left(\mathrm{M}^{+}\right.$, correct isotope distribution for $\left.{ }^{185 / 187} \mathrm{Re}\right), 635.8(\mathrm{M}-2 \mathrm{CO})$.

\section{[12[ane] $\left.\mathrm{P}_{3}{ }_{3} \mathrm{Bu}_{3} \mathrm{Re}\left(=\mathrm{C}=\mathrm{C}=\mathrm{CPh}_{2}\right)(\mathrm{CO})_{2}\right]^{+}\left(\mathrm{CF}_{3} \mathrm{SO}_{3}\right)^{-}, 5^{i \mathrm{Bu}}$}

To a cold $\left(0{ }^{\circ} \mathrm{C}\right)$ solution of $2^{i \mathrm{Bu}}(0.09 \mathrm{~g}, 0.14 \mathrm{mmol})$ in $\mathrm{CH}_{2} \mathrm{Cl}_{2}$ $\left(10 \mathrm{~cm}^{3}\right)$ was added AgOTf $(0.036 \mathrm{~g}, 0.14 \mathrm{mmol})$. After warming to room temperature the mixture was stirred for $10 \mathrm{~min}$ then recooled to $0{ }^{\circ} \mathrm{C}$. Propargyl alcohol $(0.035 \mathrm{~g}, 0.17$ $\mathrm{mmol}$ ) was then added as a solid and this was warmed to room temperature and stirred for $1 \mathrm{~h}$ to give a yellow solution and a white solid. The solution was filtered, concentrated to $\sim 2 \mathrm{~cm}^{3}$ and light petroleum $\left(10 \mathrm{~cm}^{3}\right)$ added to precipitate a dark yellow solid. This was isolated by filtration and dried in vacuo. Yield, $0.06 \mathrm{~g}(51 \%)$ (Found: $\mathrm{C}, 48.6 ; \mathrm{H}, 6.41 . \mathrm{C}_{39} \mathrm{H}_{60} \mathrm{O}_{5} \mathrm{~F}_{3} \mathrm{SP}_{3} \mathrm{Re}$ requires: $\mathrm{C}, 47.94 ; \mathrm{H}, 6.19 \%) .{ }^{31} \mathrm{P}\left\{{ }^{1} \mathrm{H}\right\} \quad \mathrm{NMR}\left(\mathrm{CD}_{2} \mathrm{Cl}_{2}\right)$ : $\delta-48.91(\mathrm{t}),-31.45$ (d) $J_{\mathrm{PP}}=30.46 \mathrm{~Hz} .{ }^{1} \mathrm{H} \mathrm{NMR}\left(\mathrm{CD}_{2} \mathrm{Cl}_{2}\right)$ : $\delta$ 7.6-7.0 (m, $\left.10 \mathrm{H}, \mathrm{C}=\mathrm{CPh}_{2}\right), 0.70\left(\mathrm{~m}, 18 \mathrm{H}, \mathrm{CH}\left(\mathrm{CH}_{3}\right)_{2}\right), 1.1-2.3$ (m, $27 \mathrm{H}, \mathrm{PCH}_{2} \mathrm{CH}_{2} \mathrm{CH}_{2} \mathrm{P}, \mathrm{PCH}_{2} \mathrm{CH}_{2} \mathrm{CH}_{2} \mathrm{P}, \mathrm{PCH} \mathrm{CH}_{2}\left(\mathrm{CH}_{3}\right)_{2}$, $\left.\mathrm{PCH}_{2} \mathrm{CH}\left(\mathrm{CH}_{3}\right)_{2}\right) \cdot{ }^{13} \mathrm{C}$ NMR $\left(\mathrm{CD}_{2} \mathrm{Cl}_{2}\right): \delta 19.82\left(\mathrm{~s}, \mathrm{C}_{\mathrm{e}}\right) ; 21.31$ $\left(\mathrm{s}, \mathrm{C}_{\mathrm{b}}\right) ; 24.81\left(\mathrm{t},{ }^{1} J_{\mathrm{PC}}=13 \mathrm{~Hz}, \mathrm{C}_{\mathrm{d}}\right) ; 24.42\left(\mathrm{~s}, \mathrm{C}_{\mathrm{i}}\right) ; 25.02\left(\mathrm{~d},{ }^{1} J_{\mathrm{PC}}=\right.$ $\left.4 \mathrm{~Hz}, \mathrm{C}_{\mathrm{h}}\right) ; 28.84\left(\mathrm{t},{ }^{1} J_{\mathrm{PC}}=10 \mathrm{~Hz}, \mathrm{C}_{\mathrm{a}}, \mathrm{C}_{\mathrm{d}}\right) ; 31.07\left(\mathrm{~d},{ }^{1} J_{\mathrm{PC}}=31 \mathrm{~Hz}\right.$, $\left.\mathrm{C}_{\mathrm{g}}\right) ; 36.48\left(\mathrm{t},{ }^{1} J_{\mathrm{PC}}=12 \mathrm{~Hz}, \mathrm{C}_{\mathrm{c}}\right) ; 45.42\left(\mathrm{~d},{ }^{1} J_{\mathrm{PC}}=35 \mathrm{~Hz}, \mathrm{C}_{\mathrm{f}}\right)$; $125.8,126.9,128.8,129.1(\mathrm{Ar}) ; 248.7(\mathrm{~s}, \mathrm{Re}=\mathrm{C}=C=\mathrm{C}) ; 133.05(\mathrm{~s}$, $\mathrm{Re}=\mathrm{C}=\mathrm{C}=C$ ). IR $\left(\mathrm{KBr}\right.$ disc, $\left.\mathrm{cm}^{-1}\right): v(\mathrm{SO})$ 1278. MS (APCI): $787.9\left(\mathrm{M}^{+}\right.$, correct isotope distribution for $\left.{ }^{185 / 187} \mathrm{Re}\right), 723.9$ $(\mathrm{M}-2 \mathrm{CO})$. 


\section{2[ane] $\mathrm{P}_{3} \mathrm{Et}_{3} \mathrm{Mn}(\mathrm{CO})_{2} \mathrm{Br}, 6^{\mathrm{Et}}$}

To a solution of $12[\mathrm{ane}] \mathrm{P}_{3} \mathrm{Et}_{3}(0.13 \mathrm{~g}, 0.42 \mathrm{mmol})$ in $\mathrm{Et}_{2} \mathrm{O}$ $\left(25 \mathrm{~cm}^{3}\right)$ was added $\mathrm{Mn}(\mathrm{CO})_{5} \mathrm{Br}(0.12 \mathrm{~g}, 0.4 \mathrm{mmol})$ as a solid This was irradiated ( $100 \mathrm{~W}$ tungsten filament lamp) for $1.5 \mathrm{~h}$ to give a yellow suspension. The solvent was removed in vacuo and the product extracted into $\mathrm{CH}_{2} \mathrm{Cl}_{2}\left(3 \times 20 \mathrm{~cm}^{3}\right)$. The solvent was reduced in volume and light petroleum added. Cooling to $-30{ }^{\circ} \mathrm{C}$ overnight yielded a yellow microcrystalline solid. Crystals suitable for $\mathrm{X}$-ray diffraction were obtained by vapour diffusion of light petroleum into a $\mathrm{CH}_{2} \mathrm{Cl}_{2}$ solution. Yield, 0.044 g (20\%) (Found: C, 40.7; H, 6.45. $\mathrm{C}_{17} \mathrm{H}_{33} \mathrm{O}_{2} \mathrm{BrP}_{3} \mathrm{Mn}$ requires: $\left.\mathrm{C}, 41.07 ; \mathrm{H}, 6.69^{\circ}\right) .{ }^{31} \mathrm{P}\left\{{ }^{1} \mathrm{H}\right\}$ NMR $\left(\mathrm{CDCl}_{3}\right): \delta 10.5$ (t), $58.6\left(\mathrm{~d}, J_{\mathrm{PP}}=50 \mathrm{~Hz}\right) .{ }^{1} \mathrm{H}$ NMR $\left(\mathrm{CDCl}_{3}\right): \delta 1.03($ br s, $9 \mathrm{H}$ $\mathrm{PCH}_{2} \mathrm{CH}_{3}$ ); 1.28 (br s, $2 \mathrm{H}, \mathrm{PCH}_{2} \mathrm{CH}_{2} \mathrm{CH}_{2}$ ); 1.47 (br s, $6 \mathrm{H}$, $\mathrm{PCH}_{2} \mathrm{CH}_{3}$ ); 1.63 (br s, $4 \mathrm{H}, \mathrm{PCH}_{2} \mathrm{CH}_{2} \mathrm{CH}_{2}$ ); 1.79 (br s, $2 \mathrm{H}$, $\mathrm{PCH}_{2} \mathrm{CH}_{2} \mathrm{CH}_{2}$ ); 1.92 (br s, $6 \mathrm{H}, \mathrm{PCH}_{2} \mathrm{CH}_{2} \mathrm{CH}_{2}$ ); 2.08 (br s, $2 \mathrm{H}$, $\mathrm{PCH}_{2} \mathrm{CH}_{2} \mathrm{CH}_{2}$ ); 2.3 (br s, $2 \mathrm{H}, \mathrm{PCH}_{2} \mathrm{CH}_{2} \mathrm{CH}_{2}$ ). IR ( $\mathrm{KBr}$ disc $\left.\mathrm{cm}^{-1}\right): v(\mathrm{CO}) 1907$ (s), 1847 (s). MS (APCI): $405.3\left(\mathrm{M}^{+}\right.$, the expected isotope ratio for ${ }^{79 / 81} \mathrm{Br}$ was observed).

\section{ROMP reactions}

In a typical experiment in a Schlenk flask, 12[ane] $\mathrm{P}_{3} \mathrm{R}_{3} \mathrm{Re}-$ $(\mathrm{CO})_{2} \mathrm{Cl}(0.02 \mathrm{~g}, 0.03 \mathrm{mmol})$ was dissolved in $\mathrm{CH}_{2} \mathrm{Cl}_{2}\left(10 \mathrm{~cm}^{3}\right)$ and $\operatorname{EtAlCl}_{2}\left(0.1 \mathrm{~cm}^{3}\right.$ of a $1.8 \mathrm{M}$ solution in toluene, $\left.0.12 \mathrm{mmol}\right)$ added via syringe. An immediate colour change to deep red occurred. This solution was stirred for $15 \mathrm{~min}$ then cooled to $0{ }^{\circ} \mathrm{C}$ and a solution of norbornene $(0.5 \mathrm{~g}, 5.31 \mathrm{mmol})$ in $\mathrm{CH}_{2} \mathrm{Cl}_{2}$ $\left(5 \mathrm{~cm}^{3}\right)$ was added via canula. This was stirred for $1 \mathrm{~h}$ and then poured onto vigorously stirred $\mathrm{MeOH}\left(100 \mathrm{~cm}^{3}\right)$ to precipitate a yellow or white solid, which was washed with $\mathrm{MeOH}(3 \times$ $\left.50 \mathrm{~cm}^{3}\right)$ and dried in vacuo $(6 \mathrm{~h}$ at $0.1 \mathrm{~mm})$.

\section{Acknowledgements}

We thank Mr Robert Haigh and Dr Thomas Albers for assistance with the X-ray crystallography and the EPSRC for support (R. J. B).

\section{References}

1 (a) R. J. Baker, P. C. Davies, P. G. Edwards, R. D. Farley, S. S. Liyanage, D. M. Murphy and B. Yong, Eur. J. Inorg. Chem., 2002, 1975; (b) R. J. Baker and P. G. Edwards, J. Chem. Soc., Dalton Trans., 2002, 2960.

2 P. G. Edwards, J. S. Fleming, S. S. Liyanage, S. J. Coles and M. B. Hursthouse, J. Chem. Soc., Dalton Trans., 1996, 1801.

3 For examples, see: J. C. Mol, in, Applied Homogeneous Catalysis with Organometallic Compounds, ed. B. Cornils and W. A. Herrmann, Wiley-VCH, Weinheim, 2000, pp. 318-332.

4 (a) P. G. Edwards, J. S. Fleming, S. J. Coles and M. B. Hursthouse, J. Chem. Soc., Dalton Trans., 1997, 3201; (b) P. G. Edwards, James S. Fleming and Sudantha S. Liyanage, J. Chem. Soc., Dalton Trans. 1997, 193.

5 (a) J. Chatt, J. R. Dilworth and G. J. Leigh, J. Chem. Soc. A, 1970, 2239; (b) J. E. Fergusson, Coord. Chem. Rev., 1966, 1, 459; (c) W. W. Randall and D. Shaw, J. Chem. Soc. A, 1969, 2867.

6 N. Boden, in Determination of organic structures by physical methods., ed. F. C. Nachod and J. J. Zuckerman., Academic Press, London, 1971, vol. 4, pp. 66-67.

7 (a) M. T. Costello, P. E. Fanwick, M. A. Green and R. A. Walton, Inorg. Chem., 1992, 31, 2359; (b) X.-L. Luo and R. H. Crabtree, J. Chem. Soc., Dalton Trans., 1991, 583.

8 (a) F. A. Cotton and R. L. Luck, Inorg. Chem., 1989, 28, 2181; (b) X. Luo and R. H. Crabtree, J. Chem. Soc., Dalton Trans., 1991, 587; (c) D. Michos, X. Luo and R. H. Crabtree, J. Chem. Soc., Dalton Trans., 1992, 1735; (d) C. Bianchini, E. Farnetti,
M. Graziani, G. Nardin, A. Vacca and F. Zanobini, J. Am. Chem. Soc., 1990, 112, 9190; (e) M. Di Vaira, S. Midollini and L. Sacconi, Inorg. Chem., 1980, 18, 3466.

9 V. K. Rybak and J. J. Ziolkowsky, Polyhedron, 1983, 2, 541.

10 G. Rouchias, Chem. Rev., 1974, 74, 531.

11 C. Bianchini, A. Marchi, L. Marvelli, M. Peruzzini, A. Romerosa, R. Rossi and A. Vacca, Organometallics, 1995, 14, 3203.

12 S. I. Hommeltoft, A. D. Cameron, T. A. Shackleton, M. E. Fraser, S. Fortier and M. C. Baird, Organometallics, 1986, 5, 1380.

13 A. M. Bond, R. Colton, R. W. Gable, M. F. Mackay and J. N. Walter, Inorg. Chem., 1997, 36, 1181.

14 (a) C. Bianchini, M. Peruzzini, F. Zanobini, L. Magon, L. Marvelli and R. Rossi, J. Organomet. Chem., 1993, 451, 97; (b) S. C. Lin, C. P. Cheng, T.-Y. Lee, T.-J. Lee and S.-M. Peng., Acta Crystallogr., Sect. C, 1986, 42, 1733.

15 N. M. Kostic and R. F. Fenske, Organometallics, 1982, 1, 974.

16 For examples of allenylidene complexes, see: $(a)$ J. P. Selegue, Organometallics, 1982, 1, 217; (b) M. I. Bruce, Chem. Rev., 1998, 98, 2797; (c) C. Bianchini, N. Mantovani, A. Marchi, L. Marvelli, D. Masi, M. Peruzzini, R. Rossi and A. Romerosa, Organometallics, 1999, 18, 4501.

17 N. G. Connelly, K. A. Hassard, B. J. Dunne, A. G. Orpen, S. J. Raven, G. A. Carriedo and V. Riera, J. Chem. Soc., Dalton Trans., 1988, 1623.

18 W. S. Greenlee and M. F. Farona, Inorg. Chem., 1976, 15, 2129

19 E. L. Muetterties, Inorg. Chem., 1975, 14, 951.

20 See, for example: (a) U. Frenzel, T. Weskamp, F. J. Kohl, W. C. Schattenmann, O. Nuyken and W. A. Herrmann, J. Organomet. Chem., 1999, 586, 263; (b) H.-J. Schanz, L. Jafarpour, E. D. Stevens and S. P. Nolan, Organometallics, 1999, 18, 5187.

21 See, for example: (a) H. Katayama, T. Yoshida and F. Ozawa, J. Organomet. Chem., 1998, 562, 203; (b) I. Del Rio and G. van Koten, Tetrahedron Lett., 1999, 40, 1401.

22 See, for example: (a) M. Picquet, D. Touchard, C. Bruneau and P. H. Dixneuf, New J. Chem., 1999, 141; (b) A. Furstner, M. Liebl, C. W. Lehmann, M. Picquet, R. Kunz, C. Bruneau, D. Touchard and P. H. Dixneuf, Chem. Eur. J., 2000, 6, 1847.

23 M. S. Sanford, L. M. Henling and R. H. Grubbs, Organometallics, 1998, 17, 5384 .

24 H. Katayama, T. Yoshida and F. Ozawa, J. Organomet. Chem., 1998, 562, 203.

25 W.-H. Leung, K.-K. Lau, Q.-F. Zhang, W.-T. Wong and B. Tang, Organometallics, 2000, 19, 2084.

26 E. L. Dias, S. T. Nguyen and R. H. Grubbs, J. Am. Chem. Soc., 1997, 119, 3887 .

27 (a) S. M. Hansen, F. Rominger, M. Metz and P. Hofmann, Chem. Eur. J., 1999, 5, 557; (b) S. M. Hansen, M. A. O. Volland, F. Rominger, F. Eisentrager and P. Hofmann, Angew. Chem., Int. Ed. $1999, \mathbf{3 8}, 1273$.

28 S. G. Davies, S. J. Simpson, H. Felkin and T. Fillibee-Khan, Organometallics, 1983, 2, 539.

29 (a) M. S. Sanford, L. M. Henling and R. H. Grubbs, Organometallics, 1998, 17, 5384; (b) S. Chang, L. Jones, C. Wang, L. M. Henling and R. H. Grubbs, Organometallics, 1998, 17, 2758.

30 P. G. Edwards, J. S. Fleming and S. S. Liyanage, Inorg. Chem., 1996, 35, 4563 .

31 N. P. Johnson, C. J. Lock and G. Wilkinson, Inorg. Synth., 9, 145

32 S. P. Schmidt, W. C. Trogler and F. Basolo, Inorg. Synth., 26, 160

33 J. Chatt, J. R. Dilworth, H. P. Gunz and G. J. Leigh, J. Organomet. Chem., 1974, 64, 245.

34 D. F. Evans, J. Chem. Soc., 1959, 2003.

35 P. H. M. Budzelaar., gNMR for Windows version 4.1., Cherwell Scientific, 1999.

36 (a) J. Akter, G. M. G. Hossain, S. E. Kabir and K. M. A. Malik, J. Chem. Crystallogr., 2000, 30, 773; (b) J. A. Darr, S. R. Drake, M. B. Hursthouse and K. M. A. Malik, Inorg. Chem., 1993, 32, 5704.

37 R. H. Blessing, Acta Crystallogr., Sect. A, 1995, 51, 33 (J. Appl. Crystallogr., 1997, 30, 421).

38 N. P. C. Walker and D. Stuart, Acta Crystallogr, Sect. A, 1983, 39, 158.

39 G. M. Sheldrick, Acta Crystallogr, Sect. A, 1990, 46, 467.

40 G. M. Sheldrick, SHELXL-97 program for crystal structure refinement, University of Göttingen, Germany, 1997. 